\title{
MILTON's MANLY ANGELS
}

\author{
By \\ Thomas James Lissington
}

\begin{abstract}
A thesis
submitted to the Victoria University of Wellington in partial fulfilment of the requirements for the degree of

Master of Arts

in English Literature
\end{abstract}

Victoria University of Wellington

MMXIX 


\begin{abstract}
The masculine nature of the angels in Paradise Lost, in conjunction with their sexuality as revealed in Book VIII, prompted C. S. Lewis to try and explain away, not entirely convincingly, any potential "homosexual promiscuity" in his Preface to the epic. But other critics are unconcerned about the angels' sexuality, probably because, unlike Lewis, they see them as essentially immaterial beings.

In what follows I argue that a complete understanding of the angels' sexuality must rest on Milton's gradual revelation of the angels' morphic substance, critical to their sexuality and gender identity. Milton's use of the conventions associated with classical pastoral in depicting the angels suggests a male homosocial model analogous with the learning institutions of Milton's own historical context - helpful when it comes to establishing the type of society, and relationships, in the heaven of Paradise Lost. Similarly, an exploration of bi-erotic elements occurring elsewhere within the Miltonic canon helps contextualise the bisexual potential of angelic desire.

With these things in mind, a comprehensive understanding of the angelic sexuality can be achieved through close study of instances of desire, and sexuality, in Paradise Lost. The strong parallel between the angels, and Adam and Eve infers the potential for their descendants to evolve into a similar state of intimacy free of "Of membrane, joynt, or limb, exclusive barrs".
\end{abstract}




\title{
ACKNOWLEDGEMENTS
}

\author{
... a grateful mind \\ By owing owes not, but still pays, at once \\ Indebted and dischargd; what burden then?
}

(Paradise Lost IV.55-57)

While the sentences that follow are often extensive in length, I feel it is apt that they are that way given Milton's own penchant for lengthy sentences. I do, however, apologise for not presenting them in the correct epic metre of ten syllables per line!

Foremost thanks must go to Dr Deborah Laurs, of Victoria's Student Support Services, without whom this thesis would have remained abandoned, and Dr Kristina McGuiness-King, Manager of Student and Academic Services, Faculty of Humanity and Social Sciences, for granting me this very final extension.

I would like to thank Dr Linda Hardy for introducing me to Milton and supervising me through the first part of this thesis. I would also like to thank both Professor Kathryn Walls (who showed me the satiric joys of Pope) and Dr Geoff Miles (likewise the Classical Tradition, in particular the study of Ovidian horror that prepared me well for Milton's portrayal of Satan, Sin, and Death's incestuous and abhorrent relations), who together took over my supervision from Dr Hardy upon her retirement: your guidance and insight has been invaluable, as well as your active encouragement and assistance during the final push to submit the thesis for examination. Thanks also is due to Dr Tatjana Schaefer, who was my head tutor during my brief stint of tutoring, and the students of both Past Masters classes that I tutored - I am glad that you appreciated the Earl Grey tea!

I am also indebted to Dr Jane Lawrence and Dr John Gregson for, respectively, initiating and confirming my ADHD diagnosis during the writing of this thesis, which has quite literally improved my life.

Thank you to Kayla Wyatt from the Humanities Faculty for your administrative support. The same goes for my proof-readers, my sister Nicola, and Georgia Hughes, and of course, Dr Deborah Laurs.

Thanks also to my past and current flatmates; other staff and students of the English department; and my other friends for your companionship and encouragement during this time; particular mention has to go to: Dr Rebecca "Bex" Smith for our regular coffee and home-made salad waterfront catch-ups; Dr Clare "Clara" Scollay née Rostron for our Wednesday afternoon crème brulée and B-grade monster movie sessions; David Kennedy for our late-night clubbing and midnight tea-drinking; my Starcraft the Boardgame competitors Anton, Cam, and Matt; and 
my Dungeons \& Dragons group of the time: Chelsea, Jonas, Eddie "Sparkles", Ben "Beast" M, Ben W, Adam "Wuffles", and James B - the latter two especially for letting me crash on their couch during the final stages of the thesis writing. Any of you that I have missed - I do apologise for the omission and please let me know - I will endeavour to include you in my second thesis due later this year!

I would also like to thank my family, my parents Peter and Jenayre, and my siblings Briar, Morgan, Nicola as aforementioned, and Anna, for supporting my education and, more importantly, exiling me to the kitchen of the various huts we stayed in during our canoe trip down the Whanganui River for the alleged crime of snoring which had the unexpected effect of making me read the entirety of Paradise Lost by candlelight, as it was the only literature I had available, being the required reading for the Renaissance Literature paper I was then taking. This authentic experience, reading it as it first would have been by his contemporaries without our modern distractions, lead to a love of Milton, and ultimately this thesis.

It is worth noting that nearing the end of the initial writing of this thesis, here in New Zealand Marriage (Definition of Marriage) Amendment Act 2013 was passed which allowed couples of any gender or sexuality to marry. In doing so, however, it effectively allowed religious organisations the freedom to refuse to marry such couples, which many, such as my current church organisation, have done, while at the same continuing the prohibition of same-sex civil unions. As anachronistic as it is, I would like to think that John Milton, being the independent religious thinker that he was with his historic willingness to challenge the institutional thinking of his day, would have advocated for a solution along the lines of allowing civil unions for those LGBTQ couples of faith rather than leaving them in the current unacknowledged and untenable position which results in many leaving their home organisation and harming their relationship with God.

While I have struggled with such issues myself, my faith is anchored in a vision of an angel that I had in my teenage years that marked my own watershed. I cannot remember if he had wings, for the angel appeared male, but he appeared to be clean cut in appearance and shone white yet a rainbow of other colours all at once with piercing blue eyes. The angel was, and still is, the most beautiful yet terrifying thing that I ever seen - I felt that it could quite literally destroy armies at a glance. Ironically, in every sense of the word, this probably motivated my interest in the thesis yet I left it unmentioned in the original text where perhaps I should have included - but like Milton's angels he remains here invisible to mortal eyes and hence the irony. So my penultimate thanks is to God and the angels, whatever the reality of their existence may be - this mystery may only be revealed in our own mortal death - but I live in hope. 
Finally, I would like to dedicate this thesis to the memory of the late Mr Martin Sims, my former chess teacher and mentor at P.N.B.H.S., who told me it was ok to be gay, or bisexual, even before I realised that I was and whose passion for chess and teaching helped make my high school days some of the best of my life. 


\section{CONTENTS}

Abstract Iii

Acknowledgements $\quad$ Iv

Chapter One: Introduction 1

Chapter Two: Angelic Matter \& Manly Angels 8

Chapter Three: Pastoral Portrayals 24

Chapter Four: Classical Bi-Eroticism 39

Chapter Five: Desire and Love 51

$\begin{array}{ll}\text { Conclusion } & 65\end{array}$

$\begin{array}{ll}\text { Works Cited } & 67\end{array}$

$\begin{array}{ll}\text { Works Consulted } & 70\end{array}$ 


\section{CHAPTER ONE: INTRODUCTION}

Gregory Bredbeck opens his article, 'Milton's Ganymede: Negotiations of Homoerotic Tradition in Paradise Regained, by citing the following passage from C.S. Lewis's Preface to Paradise Lost as an epigraph, in order to highlight what he sees as the "ease in which homoeroticism can be detected in Milton's canon and the urgency with which it is written away" (Bredbeck 262):

The trouble is, I think, that since these exalted creatures are all spoken of by masculine pronouns, we tend, half consciously, to think that Milton is attributing to them a life of homosexual promiscuity. That he was poetically imprudent in raising a matter which invites such misconception I do not deny; but the real meaning is certainly not filthy, and certainly not foolish. As angels do not die, they do not need to breed. They are not therefore sexed in the human sense at all. An Angel is, of course, always $\mathrm{He}$ (not She) in human language, because whether the male is, or is not, the superior sex, the masculine is certainly the superior gender. (Lewis 112-13)

As Bredbeck intimates, Milton's description of the angels is more problematic than Lewis claims. The context for Lewis's remarks is as follows: Raphael has been sent by God to instruct Adam, "as friend with friend" (V.229), on the dangers of free-will (V.229-238). After hearing Raphael describe the War in Heaven (V.563 ff.; VI), the Creation of the World (VII), and Astronomy (VIII.5-178), Adam reciprocates with an account of his own creation (VIII.249ff). He follows this with a complementary account of Eve's which ends with an exuberant description of Eve's beauty and charm. Raphael responds, however, by cautioning Adam about the dangers of letting Eve's outer attractiveness overwhelm his wisdom and leadership (VIII.560-94) and urges him instead to follow the path of rational "true Love" (VIII.589) that may evolve into "heav'nly Love" (VIII.592) rather than sink in "carnal pleasure" (VIII.593). It is this discussion of love that leads Adam, somewhat hesitantly (VIII.614), to ask if the angels, or "heav'nly Spirits" (VIII.615), share a similar love. If they do, then how is it expressed? Is it through "virtual" "looks" or by their mixing of "irradiance" through actual "immediate" contact: "how thir Love / Express they, by looks onely, or do they mix / Irradiance, virtual or immediate touch?” (VIII.612-617). Raphael's answer is what causes such consternation for Lewis:

To whom the Angel with a smile that glow'd

Celestial rosie red, Loves proper hue, Answer'd. Let it suffice thee that thou know'st 
Us happie, and without Love no happiness.

Whatever pure thou in the body enjoy'st

(And pure thou wert created) we enjoy

In eminence, and obstacle find none

Of membrane, joynt, or limb, exclusive barrs:

Easier then Air with Air, if Spirits embrace,

Total they mix, Union of Pure with Pure

Desiring; nor restrain'd conveyance need

As Flesh to mix with Flesh, or Soul with Soul. (VIII.618-629)

There is a repeated emphasis on the holy nature of this angelic union by Raphael through the repetition of "pure" at lines 622, 623, and the "Union of Pure with Pure" at 627. Despite this, Lewis feels that he has to defend the angels from the possibility of "filthy" (113) "homosexual promiscuity" (112-13), revealing his prejudice, a product of his own social context. But any suggestion that Raphael himself has anything to be ashamed of is forestalled by Milton's application of "proper": "with a smile that glow'd / Celestial rosie red, Loves proper hue" (VIII.618-19, italics mine).

As to the rest of Lewis's argument: although he claims that "As angels do not die, they do not need to breed", it appears that, nevertheless, the spiritual form possesses the capacity to reproduce. This is shown by Satan's relationship with the (albeit fallen and allegorical) persons of Sin and Death. In Book II, when Satan is confronted by Death at the gates of hell, Sin interposes herself and reminds him of her former relationship to him while he was still an angel in heaven:

Then shining heav'nly fair, a Goddess arm'd

Out of thy head I sprung: amazement seis'd

All th' Host of Heav'n; back they recoild affraid

At first, and call'd me Sin, and for a Sign

Portentous held me; but familiar grown,

I pleas'd, and with attractive graces won

The most averse, thee chiefly, who full oft

Thy self in me thy perfect image viewing

Becam'st enamour'd, and such joy thou took'st

With me in secret, that my womb conceiv'd

A growing burden. (II.757-767)

Sin's story contains three instances of breeding: firstly, Sin comes from Satan's head fully formed (II.758), as a literal embodiment of his rebellious thoughts - an example of what one might call asexual reproduction. (This is of course a demonic parody of Athena's birth from the head of Zeus.) Then, as Sin recalls, Satan “[took] joy” with her and conceived their son, Death (II.765-67), an example of sexual reproduction. Horrifically Death emerges only to rape Sin with the result that she conceives a pack of hounds (II.781-802): a second example of sexual reproduction. As Sin comes from Satan alone, it is logical to assume that she is made of the same substance as the angels. An identical logic applies to Death, who as an offspring of these two related spirits should be a 
spirit himself. This is evidenced by Death's ability to both grow in size (II.704-6) - an inversion of the aspect of spirit mentioned by Milton earlier in the council in Pandemonium: "Thus incorporeal Spirits to smallest forms / Reduc'd thir shapes immense" (I.789-90). Therefore, Lewis's assumption that angels cannot reproduce is flawed, for Satan provides an obvious counterexample. Even if one argues that, despite their extensive characterisation, that Sin and Death are purely metaphorical allegory, there is the biblical tradition of the heroic offspring of the angelic 'sons of god' alluded to in the Book II (461-63).

As to Lewis's following implication that the angels are "not therefore sexed in the human sense at all' (italics mine), the truth of the matter is more complicated. In the course of his epic catalogue of the fallen angels in Book I, Milton comments on the multi-sexed potential of the spirits:

For Spirits when they please

Can either Sex assume, or both; so soft

And uncompounded is thir Essence pure,

Not ti'd or manacl'd with joynt or limb,

Nor founded on the brittle strength of bones,

Like cumbrous flesh; but in what shape they choose

Dilated or condens't, bright or obscure,

Can execute thir aerie purposes,

And works of love or enmity fulfill. (423-431)

Thus it appears that spirits can choose to assume the appearance of one or both sexes. But despite having this inherent flexibility, it appears that many of the spirits in Paradise Lost choose to remain as one specific sex. Sin, for instance, is born in an obviously female form and uses her feminine charm to beguile Satan and the other angels (II.761-63). After her seemingly sexual encounters with both Satan and Death it is she that bears the offspring, conforming to the female biological role in both cases. Likewise, Satan's physical maleness is reinforced by his role in the conception of Death (II.765-67). Similarly the faithful angels remain uniformly male, both physiologically, and in their behaviour (as I will demonstrate later). ${ }^{1}$

Lewis endeavours to explain away Milton's use of the masculine pronoun in describing the angels by saying it is due to the grammatical conventions of the English language, and that it is thus not a reflection of the angels' physical sex or gender: "An Angel is, of course, always He (not She) in human language" (113). But in doing this Lewis is overlooking conflicting evidence from the

\footnotetext{
1 Throughout Paradise Lost the term "angel" is reserved for the spirits that remain "heavenly"; after the fall of Satan and those that follow him, they are described as spirits but not angels, losing their angelic brightness but still retaining other aspects of the spiritual form.
} 
text itself. Adam for one thinks that the angels are all, and exclusively, male; after hearing of Eve's disobedience he says as much:

O why did God,

Creator wise, that peopl'd highest Heav'n

With Spirits Masculine, create at last

This noveltie on Earth, this fair defect

Of Nature, and not fill the World at once

With Men as Angels without Feminine,

Or find some other way to generate

Mankind? (X.575-82)

Here Adam is clearly identifying the angels as male, as opposed to female, and not merely grammatically so. In fact, despite their inherently morphic nature, the angels seem to have a default masculine form. This is shown by the disguised Satan's return to his original male form at the touch of Ithuriel's spear (IV.810-11): "for no falshood can endure / Touch of Celestial temper, but returns / Of force to its own likeness" (IV.811-13).

Thus while the faithful angels in Paradise Lost are like the other spirits able to change their form and appearance at will, it can be argued that they possess a base male form to which they return, and they may also engage in a form of sexual intimacy with each other. Despite what Lewis argues, it appears that this mutual sexuality of the male angels is relatively consistent with our modern idea of natural homosexuality. Although homosexuality posed such a problem for Lewis, other critics seem unperturbed to the extent that they pay little if any attention to the angels' sexuality. John R. Knott Jnr. (writing in 1970) describes in great detail the pastoral setting where the angels eat and sleep, yet avoids any mention of the angel's sexuality. Instead he attributes a "highly refined bliss that depends not on the gratification of the senses but on the immediate presence of God" to the angels that contrasts with the first human pair whose "joy is always a matter of sensuous pleasure" (491).

This disparity between the perspectives of Lewis and Knott is attributable to the broad difference in their understanding of the nature of the heavenly spirits in Paradise Lost. There are two areas of contention regarding the angelic form and each has direct implications for an understanding of angelic sexuality. The first is whether spirits such as the angels are completely intangible or have some degree of physical substance. In 1940, P. L. Carver had sought to reconcile these two alternatives by arguing that Milton had initially intended to portray the angels as Aquinas sees them, namely beings purely of "intellect and will" (Carver 430), but that as the epic evolved he was influenced by Tertullian's ideas and later gave the angels physical substance (418-20; 43031). Lewis clearly follows the second view (112), and in asserting the physical nature of the angels becomes concerned within the possible sexual implications. But for E. L. Marrila (writing in 1953) 
the angels lack physical bodies, and their "conjugal love" (485) represents a "sexual union of "pure lovers"' (486). Evidently, then, the question of the angels' sex (or gender) arises only for those who see their form as being somewhat physical. For Marilla, it seems that since the angels lack physical bodies a discussion of their sex or gender is irrelevant. But for Lewis, the physicality of the angels means that their sexuality needs to be addressed. The second issue is contingent to the first: to what extent does the multi-sexed potential of the angels' physical appearance reflect that of the real spiritual form: are they sexless, single-sexed, or multi-sexed?

Thus a discussion of the sexuality of the angels is dependent on how comparable to humans they are: are they sexed and gendered physical beings, like Adam and Eve, or are they sexless and disembodied intellects, or something in between $?^{2}$ Thus, even Bredbeck, despite raising the homoerotic potential of the angels (262), later implies that they lack physical bodies, being in a world "in which there is no difference, only similarity" and where "the Word is still the Word, and not the flesh" (274). Thus he contrasts what he sees as the uniformly insubstantial angels with the fleshly dichotomy of the first human couple.

Likewise, to many other critics the apparent maleness of the angels appears to be irrelevant presumably due to what they see as their sexless nature. Joseph H. Summers, in 1962, argued that the union of the angels represents "the angelic transcendence of the love of man and woman", but he neglects to mention the sex or gender of the angels themselves (7). Barry Gross, in 1967, briefly asserted a similar sentiment (97), but his main focus is on the sexuality and self-love of Adam and Eve. In 2000, Kent R. Lehnhof described the angels as enjoying a "sublime sexuality" in expressing their love for each other (69). He makes no mention of their sex or gender, but draws a connection between the total nature of their unions and their own "indivisible" nature (80-81). In 2010, Barbara Lewalski delineated the pastoral nature of the angels, including "sex" amongst their activities, but she neglects to discuss their maleness (89). This is perhaps surprising, given the homoerotic associations of classical pastoral, and the homosocial focus of Milton's longer pastoral poems.

Other critics see the angels as being multi-sexed. Elspeth Graham, in 1992, attributed to the angels" "polymorphous perversity", describing their ability to "blend with each other" as an expression of "Voluntary undifferentiation" (137-38). In 2000 Harold Bloom described the angels as androgynous and Satan and Beelzebub as lovers (118), the latter point also being made by Goldberg (196). Empson also discussed the possibility of a homosexual element to the angels' ${ }^{2}$ To avoid possible confusion I will be using sex only when referring to the visible characteristics male and/or female form, and not the act itself
(which will instead be alluded to by sexual and its derivatives); I will also be making use of gender to refer to masculine and/or feminine self-identity. 
"cosy interpenetration" (106-7). Satan describes the torment of the fallen angels in hell "Where neither joy nor love, but fierce desire, / . . , / Still unfulfill'd with pain of longing pines" (IV.50911); Empson argues that their inability to satisfy this desire is because "God had made their substance thicken just enough to keep them from their pleasure of total interpenetration" (53).

Holstun describes the angels as male, within a "complexly interrelated fraternity of divine, angelic and human males" (852), but makes no comment regarding their sexuality; his focus is on female homoeroticism. In 2001 Gregory Chaplin describes the angels as representing an idealisation of Early Modern male friendship through their "disembodied unions" (285), evoking the mingling of souls in De Montaigne's "Of Friendship": "Our souls pulled together in such unison together" (140); for Chaplin the angels are male in gender but are not physically sexed so their union is therefore nonsexual (285).

The equality and eroticism of their incorporeal union is representative of Milton's appropriation of the Neoplatonic male friendship ideal into companionate marriage (289-92). More recently, in 2009, Jonathan Goldberg argued in favour "angelic sex[uality]" (194). For Goldberg, Lucifer and Beelzebub are "undoubtably one angelic couple" and their intimacy represents "the kind of relationships that angels have with one another and that Raphael celebrates in the complete oneness of bodily interpenetration available to them (196). In 2010, Joad Raymond argued that the angels lack physical bodies yet have shapes (290), appear male yet possess a "natural sexlessness", and enjoy "pure promiscuity" (283). Critics such as Sugimura, 2009, have argued that as the angels are incorporeal they "are without bodies and without matter" (176). Karma deGruy (in 2012) explores the homoeroticism between Raphael and Adam (133-34), and sees such contradictions in Milton's portrayal of how "angelic desire is and isn't homosexual" as a conscious reflection of the divided Eden (135). For her "Flesh and body are not synonyms for Milton" (118); the angelic bodies have substance despite lacking corporeal flesh (121).

There are also some odd readings. Stapleton, in 1999, misreads Raphael as blushing in embarrassment in his brief mention of the angels' sexuality (101), missing the angel's emphasis on purity. Last year (2012) Joe Moshenska described the "airy commingling of angels" (2) as "sexual intercourse" (8) but (again rather oddly given the context of the passage) disputes its superiority over human intercourse (9). In 2008, Andrew Escobedo briefly alludes to the sexuality of the angels through contrast with Vondel: for the latter's angels, unlike Milton's, their lack of sexual ability results in their jealousy of Adam and Eve (793). But frustratingly, Escobedo restrains from any further discussion of the implication for Milton's angelic sexuality.

In what follows I will focus on the sexuality of the angels within the literary, and historical, context of Milton's writings. I shall argue that (i) the angels possess a degree of physicality despite 
their morphic spirit, (ii) that not only do they possess a base form that is male, but also that the faithful angels have a corresponding, and communal, masculine gender identity that harmonises with the duties for which they were created, (iii) these male angels have an active sexuality that has some resemblance to human physical sexuality, with the obvious implication of homosexual relations, and (iv) that the angels also have a capacity for attraction to females which implies a broader degree of attraction that falls outside our modern heterosexual-homosexual binary and instead evokes the bisexual potential common to the classical tradition.

I will firstly establish the extent to which the angelic substance can be considered to be material, as opposed to insubstantial, for as we have seen the practical relevance of the angels' sex, gender and sexuality hinges on the angels possessing a degree of materiality. Secondly I will establish the male sex and masculine gender identity of the angels through both a direct textual analysis of Paradise Lost, as well as the masculine implications of the angelic society's pastoral setting and homosocial relationships in reference to earlier works; each of these elements appear within Milton's major pastoral poems: "Lycidas", Epitaphium Damonis ("Damon's Epitaph"), and the "Masque" ("Comus"). Thirdly, I turn to an analysis of bi-eroticism in Milton's Paradise Regained and the elegies with reference to the works of Boehrer, Bredbeck, and Summers. Upon these foundations I shall then examine the sex, gender and sexuality of the Miltonic angels through close analysis of the relevant passages in Paradise Lost. 


\section{Chapter Two: Angelic MatTer \& MANly ANgels}

Reaching a comprehensive understanding of the substance of the angels and other spirits is complex as it requires the untangling of several contradictory elements that have enabled critics to both argue for materiality and deny it completely. While Milton, on one hand, uses such terms as "incorporeal", "ethereal" and "airy" to describe the spiritual essence of the angels, on the other he emphasises their similarity to corporeal humanity through their sleeping, eating, and sexual intimacy.

The various aspects of the angels' nature within Paradise Lost are gradually introduced throughout the poem, in a succession of narratorial asides and instances that progressively expand the reader's comprehension of the morphic nature of the heavenly essence. This understanding is then augmented by Raphael's dialogue with Adam, where the angel outlines the various aspects of the angelic physiology: eating and digestion, sleep, incorporeality, and ultimately sexuality.

The first asideI.423-31, describes the morphic ability of the angelic spirits' "essence" (I.425) which allows them to assume either or both sexes (I.424) and adjust their appearance according to their purposes (I.430-31). It arises within the epic catalogue of the fallen angels to explain the respectively male and female appearances of the "Baalim and Ashtaroth" (I.422), the latter which includes "Astarte”, the Phoenician "Queen of Heav'n” (I.439). As the masculine Moloch (I.392) and Chemos (I.406) have already been described without need of such explanation it is clear that Milton's aside is intended to explain how some of the previously masculine fallen angels now appear as female goddesses.

The passage itself anticipates Raphael's final description of the angels' sexuality; for "Not ti'd or manacl'd with joynt or limb" (I.426, italics mine) foreshadows the angels who "obstacle find none / Of membrane, joynt, or limb, exclusive barrs" (VIII.625). But the first passage describes difference and leads to a series of oppositions describing the extremes available to the general spiritual essence. Spirits can make themselves either "Dilated or condens't", "bright or obscure" so as to "execute thir aerie purposes" and to "fulfil" their "works of love or enmity". The former of each of these oppositions, aligns more with the obvious purposes of the faithful angels: "Dilated", "bright", and "love"; the latter correlates more with the subversive intent common to the fallen spirits: "condens't", "obscure", and "enmity". The free will of the spirits is thus reflected in the very form they choose to assume. In contrast to this, in describing the sexuality of the faithful heavenly spirits, Raphael speaks in terms of likeness: unions of "Air with Air", "Flesh . . . with 
Flesh" and "Soul with Soul". These two passages thus highlight two different, yet complementary, implications of the "uncompounded" (I.425) spiritual essence.

The first book of Paradise Lost ends with a further example of the morphic essence as the lesser "incorporeal Spirits to smallest forms / Reduc'd thir shapes immense" to fit within the "narrow room" (I.778-79) of the outer hall allowed to their "Throng numberless" (I.780). Fallon cites this use of "incorporeal" as evidence of the spirits' materiality due to their need to contract to fit within Pandemonium (142). In contrast, their superiors, the "great Seraphic Lords and Cherubim" (I.794), being further within, in "close recess and secret conclave" (I.795), remained "in thir own dimensions like themselves" (I.793). An inversion of this ability is displayed in Book II by the wraithlike allegory of Death who, when challenged by Satan, grows "tenfold / More dreadful and deform" (II.705-6). Satan himself provides multiple instances that illuminate the morphic potential available to the spiritual essence, assuming the form firstly of a lesser angel, the "stripling Cherube" (III.636), and then those of various animals, in order to infiltrate Eden and avoid the watchful gazes of both Uriel, and Gabriel's angelic guards. Two of the latter discover Satan, "Squat like a Toad, close at the eare of Eve" (IV.800), and we learn something more about the nature of the angelic spirit: despite its inherent ability to change in form and size it can be forced to return to its "own likeness" (IV.800) at the (physical) "Touch of Celestial temper" (IV.799). This may be why, for Satan's actual temptation of Eve, he possesses an actual animal known to the couple, rather than taking on the mere form of an anonymous beast. For Sugimura, the fact that Satan is able to possess the serpent shows that he is immaterial; as a material being he would be unable to possess another material creature (191). But close examination of the possession passage reveals that Satan enters the serpent through the mouth (IX.187), the same way that material food and liquid enter the animal; both the "liquid texture" (VI.348) of the spirits and their ability to shrink in size, make it seem feasible for a material Satan to enter the snake's body in this manner. His influence over the serpent's desires is an extension of his ability to manipulate the dreams of Eve (V.35-91). The necessity to physically possess the serpent, however, is not something that Satan feels comfortable with:

O foul descent! that I who erst contended

With Gods to sit the highest, am now constraind

Into a Beast, and mixt with bestial slime,

This essence to incarnate and imbrute (IX.163-66)

His distaste for being "contraind" within the serpent, reflects the earlier reduction of the lesser fallen spirits, and implies a physicality which is strengthened by his spoken disdain for having to mix his "essence" with the serpent's "bestial slime". 
It is not only the fallen spirits who show the ability to change their form: Raphael, in descending to Eden, ambiguously "seems" (V.271) to take on the form of a phoenix to the birds that see him, returning to his "proper shape" (V.276) on arrival. It is unclear, however, whether Raphael actually changes his form, or merely appears birdlike when flying due to his three pairs of wings. Michael, however, clearly assumes human form for the final meeting (X.239-48). Like Satan, Michael also possesses power involving sleeping, using various substances to make Eve sleep (XI.367-68) and to give Adam his prophetic visions of the future (XI.412-20).

It is the two further aspects of the spirit that are described by Raphael in his visit to Adam that arouse the most controversy. The second is the description of angelic sexuality that is our focus, appearing at very end of the dialogue. But at the beginning of the discussion Adam raises a question, which also refers to the physiology of the angels, namely: do angels eat? (V.397-402). Raphael's reply is in the affirmative (V.404-13) and leads to a description of the rising food-chain of creation (V.414-230) for "whatever was created, needs / To be sustaind and fed" (V.414-15). Thus even the "purest Spirits" (V.406), being “pure / Intelligential substances" (V.407-8), require sustenance, as do their "Rational" (V.409) human counterparts who are only "in part / Spiritual" (V.405-6). From this, Sugimura seeks to argue that the angels are merely immaterial intelligences (159). But it seems clear that the angels are able to engage physically with corporeal food, for they have:

Within them every lower facultie

Of sense, whereby they hear, see, smell, touch, taste,

Tasting concoct, digest, assimilate,

And corporeal to incorporeal turn. (V.410-13)

Thus Raphael describes heaven as providing similar sustenance to that provided by Eden:

in Heav'n the Trees

Of life ambrosial frutage bear, and vines

Yield Nectar, though from off the boughs each Morn

We brush mellifluous Dewes, and find the ground

Cover'd with pearly grain (V.426-30).

The "pearly grain" seems likely to be an allusion to the biblical manna that came from heaven (Exod. 16:13-15). Raphael then proves his point by eating; the narrator comments that the angel does so not "seemingly" (V.434), "nor in mist, the common gloss / Of Theologians" (V.435--36), but rather with the "keen dispatch / of real hunger, and concoctive heate / To transubstantiate; what redounds, transpires / Through Spirits with ease" (V.436-39). The Miltonic narrator then invokes the metaphor of an alchemist seeking to turn iron into gold, to illuminate how the angel can turn such earthly food into incorporeal sustenance: 
... nor wonder; if by fire

Of sooty coal the Empiric Alchimist

Can turn, or holds it possible to turn

Metals of drossiest Ore to perfet Gold

As from the Mine. (V.439-43).

Thus angelic digestion is described as akin to an alchemical process where the earthly food is purified into a higher form. Having learned this, Adam, after they have finished eating (V.451), wants to know more about Raphael and the other angels, whose "excellence", "radiant forms", and "high Power" "Transcend his own" (V.456-8). So he asks Raphael why he has eaten so hungrily of these "earthly fruits" (V.464) when he has experienced the superior food of "heaven's high feasts" (V.464-67)? Raphael's reply is seen by many critics to be the defining passage of Milton's monism, or the idea that everything in existence is made from "one first matter" (V.472), which necessitates a lack of separation between body and soul as they are instead made from the same substance:

O Adam, one Almightie is, from whom All things proceed, and up to him return, If not deprav'd from good, created all Such to perfection, one first matter all, Indu'd with various forms, various degrees

Of substance, and in things that live, of life (V.469-74)

From God this first matter comes, and the nearer to him the "more refined, more spirituous, and pure" (V.475) it is:

Each in thir several active Sphears assignd, Till body up to spirit work, in bounds

Proportiond to each kind. (V.477-79)

Thus Raphael describes a spiritual food chain of sorts:

So from the root

Springs lighter the green stalk, from thence the leaves

More aerie, last the bright consummate floure

Spirits odorous breathes: flours and thir fruit

Mans nourishment, by gradual scale sublim'd

To vital Spirits aspire, to animal,

To intellectual, give both life and sense,

Fansie and undemanding, whence the Soule

Reason receives, and reason is her being,

Discursive, or Intuitive; discourse

Is oftest yours, the latter most is ours,

Differing but in degree, of kind the same. (V.479-90)

Following this description of their similarity to each other, Raphael raises the possibility that Adam, and his kin, may one day eat with the angels (V.493-95) and likewise finding the heavenly food "No inconvenient diet" (V.495) may eventually evolve into spirits themselves: 
And from these corporal nutriments perhaps

Your bodies may at last turn all to Spirit,

Improv'd by tract of time, and wingd ascend

Ethereal, as wee, or may at choice

Here or in Heav'nly Paradises dwell;

If ye be found obedient....

(V.496-501)

As Fallon points out, this passage not only indicates the potential spiritualisation of man but it also "implies the corporeality of the angels" (142).

What I think Milton means by "incorporeal" appears in the next revelation regarding the angelic essence - they lack the fixed structure of earthly creatures:

Yet soon he heal'd; for Spirits that live throughout.

Vital in every part, not as frail man

In Entrailes, Heart or Head, Liver or Reines,

Cannot but by annihilating die;

Nor in thir liquid texture mortal wound

Receive, no more then can the fluid Aire:

All Heart they live, all Head, all Eye, all Eare,

All Intellect, all Sense, and as they please,

They Limb themselves, and colour, shape or size

Assume, as likes them best, condense or rare. (VI.344-53)

The angels, and other spirits, lack a fixed anatomy; hence they are incorporeal as they literally lack the fixidity of a compartmentalised corporeal body. But this does not mean that they lack substance. Rather their "liquid texture" and lack of vital organs makes them difficult to destroy though they can still feel pain (VI.327). Thus the angels are still material despite their difference in structure.

The final aspect of the angels is their sexuality, where Milton reveals that when the "liquid texture" of the heavenly spirits join, "Total they mix" (VIII.627): the ultimate aspect of the angels, to which the poem has been gradually building. For as we have seen, Milton has provided the reader with a developing understanding of the morphic and fluid physiology of the angels, culminating in the confirmation of their sexuality and Satan's physical possession of the serpent in Book IX. We do see many of these aspects exercised throughout the following book; the allegorical Sin grows wings (X.224), then she and Death employ their new found power (284) to forge a physical bridge connecting hell to earth (252-324). We also have Satan's unseen return (441-48), his assumed brightness (449-52), the divine punishment that is the serpentine transformation (X.504-77), and the spontaneous birth of Discord from Sin (707). Each of these feats, however, provides little new information on the nature of the spiritual essence; these are merely minor developments on what is already known: the ultimate assertion on the nature of the angelic essence is the acknowledgement of their physical sexuality. This has the further 
implication of cementing Sin and Death into being actual spirits rather than mere allegory, through the actualisation of their sexuality foreshadowed in Book II.

To establish the degree to which the angels of Paradise Lost can be considered to be engaging in homoerotic or homosexual behaviour, we need to consider both the extent to which the angels can be considered to be male as well as how they behave in terms of both attraction and sexual intimacy. To completely understand this angelic sexuality though, we need to determine to what extent they are male and/or female. But as spirits, the angels can change the sex of their physical appearance at will. Therefore to establish whether or not a certain spirit is male or female requires not only an understanding of the sex of their base form but also an understanding of their gender identity and how they perceive themselves and each other. To aid with our understanding of the former we will look more closely at the context of their portrayal in Paradise Lost, then for the latter we will explore the implications of Milton's use of pastoral motifs in describing their heavenly habitat and society.

To start this analysis it seems best to look first at the several descriptions of Adam and Eve, as the most concrete examples of masculinity and femininity respectively in Paradise Lost, to establish a standard of both sex and gender against which we can measure the angels and other gendered spirits and personifications. We first encounter Adam and Eve amongst frolicking animals in Book IV:

Two of far nobler shape erect and tall, Godlike erect, with native Honour clad In naked Majestie seemd lords of all, And worthy seemd, for in thir looks Divine The image of thir glorious Maker shon, Truth, wisdom, Sanctitude ${ }^{3}$ severe and pure, Severe but in true filial ${ }^{4}$ freedom plac't; Whence true autoritie in men (IV.288-95)

Significantly, the first eight lines provide no distinguishing features between the two; Milton had briefly used a similar technique when introducing the figures of Death and Sin: "Before the gates there sat/ One either side a formidable shape" (II.648-49). Both examples give an illusion of equality/sameness, before shattering it. Here in the following lines Milton highlights how the disparity in Adam and Eve's physical appearance reflects that of their intended roles:

\footnotetext{
3 1. a. The quality of being holy or saint-like; holiness, sanctity. Now rare. [NB. This line is quoted by the OED as an example of this meaning]"sanctitude, n.". OED Online. June 2012. Oxford University Press. 31 July 2012 <http://www.oed.com/view/Entry/170504 >. ${ }^{4} 1$. Of or pertaining to a son or daughter. a. Of sentiments, duty, etc.: Due from a child to a parent. (OED)
} 
... though both

Not equal $1^{5}$, as thir sex not equal seemd;

For contemplation hee and valour formd,

For softness shee and sweet attractive Grace,

Hee for God only, shee for God in him (IV.295-99).

Adam, it appears, is made both for thinking and bravery, Eve for gentleness and attractiveness: traits that are strongly aligned with their respective genders. While this is uncomfortable to our modern sensibilities, Milton clearly ascribes to the patriarchal model of his Seventeenth Century context that views the male as inherently superior to the female. The last line highlights the unequal nature of their roles: Adam is created "for God only" whereas Eve is made for "God in him [Adam]", alluding directly to the creation of Eve specifically to be a companion for Adam. Here is, in a nutshell, the hierarchy and purpose of God, Adam, and Eve. Adam is "formed" only for God, but Eve, formed from Adam's rib, is made "for God in him". The difference is that Adam is "only" made for God, whereas Eve is made for God also but "in [Adam]". Since Adam is made in the image of God, it is implied here that the relationship of Eve to Adam is a reflection of the relationship of Adam to God. Adam's deference to God is reflected in Eve's to him, creating a hierarchy that ascends from Eve to Adam, and from Adam to God. Just as Adam is created to obey and honour God, Eve in turn is intended to do the same for Adam. However there is also the implication that Adam is independent, answerable "only" to God, whereas Eve is dependent on Adam: "in him". These contrasting tropes of male independence and female dependence are reinforced by the repeated emphasis on male dominance and female submission elsewhere in Paradise Lost. ${ }^{6}$ It is clear from the descriptions of both Adam and Eve that their physical appearance not only reflects the image of God (IV.291-92), but the differences between them reflect the different purposes for which they were created.

These gendered traits are further developed in the physical descriptions that follow, as the lines relating to Adam show his physical superiority as well as his natural leadership:

His fair large Front and Eye sublime declar'd

Absolute rule; and Hyacinthin Locks

Round from his parted forelock manly hung

Clustering, but not beneath his shoulders broad (IV.300-3)

5 2. a. Possessing a like degree of a (specified or implied) quality or attribute; on the same level in rank, dignity, power, ability, achievement, or excellence; having the same rights or privileges. Const. to, with. OED: "equal, adj. and n.". OED Online. June 2012. Oxford University Press. 31 July $2012<$ http://www.oed.com/view/Entry/63695>.

${ }^{6}$ Such examples include the submissive role of Sin in relation to Satan's rulership in Book II "where I shall reign / At thy right hand voluptuous, as beseems / Thy daughter and darling..." (II.868-70); Also Night's silence whilst Chaos speaks of the intrusions upon her realm (II.1000-6). 
This description both reflects his masculine role as leader and protector, "Absolute rule", (IV.301), but at the same time emphasises his physical beauty: his "fair large" forehead or face; noble eyes, "eye sublime"; and "shoulders broad" (IV.303) over which "hyacinthine locks" (IV.301) fall "Clustering" (IV.303) in a "manly" (IV.302) way. The use of "Hyacinthin" in describing Adam's hair, overtly compares it to the clustering hyacinth flower, but also alludes to the mythical figure of Hyacinth, lover of Apollo, after whom the flower was named and who was renowned for his youthful beauty. Thus Adam appears not only as strong and courageous, but also noble and handsome: both physically and mentally a paragon of Miltonic manhood. The description also emphasizes order and control; the Oxford English Dictionary quotes from this very passage in defining "sublime" as "Noble, dignified, or stately in bearing, demeanour, or appearance" (OED A. 3. a.), a bearing that reflects his right as an "Absolute" ruler (IV.301) and is also shown by the restrained nature of his "locks" (Ibid) that fall "not beneath his shoulders broad" (IV.303).

In a similar way, Eve's physical description reflects her "attractive grace" and "softness", but also her natural "submission" to Adam:

Shee as a vail down to the slender waste

Her unadorn'ed golden tresses wore

Dissheveld, but in wanton ringlets wav'd

As the Vine curles her tendrils, which impli'd

Subjection, but requir'd with gentle sway, And by her yielded, by him best receivd, Yielded with coy submission, modest pride, And sweet reluctant amorous delay (IV.304-11).

The "Dissheveld" hair of Eve, in contrast to the neatly parted and shorter hair of Adam, is long and unruly, yet still in curls representing her need for the "gentle sway" of Adam's governance. As Adam's beauty is fixed, based on his noble physique, Eve's, like her hair, possesses an attraction that is both "golden" and teasingly sexual: "coy submission", "modest pride", "sweet reluctant amorous delay". The sensuality associated with Eve's feminine appearance seems appropriate considering her destined role as the "Mother of [the] human race" (IV.475); her fertile potential is contingent with eroticism. ${ }^{7} \mathrm{~A}$ few lines later both are compared favourably to their descendants, according to their respective genders:

${ }^{7}$ Sin displays a feminine eroticism that aids in her seduction of Satan, resulting in the conception of Death (II.762-67). 
So hand in hand they passd, the lovliest pair

That ever since in loves imbraces met,

Adam the goodliest man of men since borne

His Sons, the fairest of her Daughters Eve (IV.321-24).

This "lovliest pair" (IV.321) is described by two superlatives: Adam is the "goodliest of... / His Sons" (323-24) whereas Eve is the "fairest of her Daughters" (324). Despite our modern association of 'good' with morality, here "goodliest" in its Seventeenth Century context, is closer to the meaning of "fair" than one might think: both are used to describe the attractive nature of an individual. The base adjective 'goodly' is defined as meaning “Of good appearance'; good-looking, well-favoured or proportioned; comely, fair, handsome" (OED 1.) whereas 'fair' is defined as "Beautiful to the eye; of pleasing form or appearance; good-looking" (OED A.I.1.); the description of Eve here (IV.324) is cited as example of its application in describing “... persons; chiefly with reference to the face... Also of the body or its parts" (OED A.I.1.a.). While it appears that 'goodly' and 'fair' could in some instances be used interchangeably, as both adjectives share the meaning of "good-looking"; from this context it seems that their use here not only emphasises their attractiveness but also the gendered differences in their appearance.

It seems that "goodly" differs from "fair" in that the former refers more to an objective anatomical ideal whereas the latter is more subjective as it evokes an emotional effect in the viewer. For "handsome", a synonym of "goodly", is defined as: "Having a fine form or figure (usually in conjunction with full size or stateliness)" (OED A.6.a.); "well-proportioned" 10 similarly refers to the physical form. Whereas "fair" seems to necessitate a emotional response in the onlooker: "beautiful to the eye"; "beautiful" itself is defined as "Excelling in grace of form, charm of colouring, and other qualities which delight the eye, and call forth admiration" (OED A.1.). Similarly "pleasing" implies a response from a subject, describing here a "form or appearance" "That pleases; that gives pleasure or satisfaction" (OED 1.). Of course the moral undertones of "goodiest" and "fair" [italics mine] hark back to the moral qualities highlighted in their initial shared description: "for in their looks divine / The image of their glorious maker shone, / Truth, wisdom, sanctitude severe and pure" (IV.291-93). The description of Adam as the goodliest of his male descendants and Eve as the fairest of hers thus highlights succinctly both their shared beauty and

\footnotetext{
8 The term 'good' is associated with the inherent purity/goodness of the Genesis creation account - where God pronounced his creations to be "good"

"From both descriptions: "appearance" is defined as "The state or form in which a person or thing appears; apparent form, look, aspect" (OED 11.a.).

10 "well-favoured" refers back to the other synonyms: "Handsome or attractive in appearance, good-looking" (OED a.).
} 
moral qualities, but also the differences associated with their respective genders. They each exhibit complementary masculine and feminine tropes here: Adam is physically strong and brave, Eve is weak and gentle; he is handsome, she is beautiful; he is controlled and orderly, she is unruly and requires order; he leads, she follows.

This contrast between the gendered Adam and Eve is congruent with the perspective of Satan who, in a monologue, reveals the reasoning behind his choice to seduce Eve over Adam:

Then let me not let pass

Occasion which now smiles, behold alone

The Woman, opportune to all attempts,

Her Husband, for I view far round, not nigh,

Whose higher intellectual more I shun,

And strength, of courage hautie, and of limb

Heroic built, though of terrestrial mould,

Foe not informidable, exempt from wound,

I not; so much hath Hell debas'd, and paine

Infeebl'd me, to what I was in Heav'n.

Shee fair, divinely fair, fit Love for Gods,

Not terrible, though terrour be in Love

And beautie not approacht by stronger hate (IX.479-91)

Here Adam is again distinguished by masculine traits: his "higher intellectual... and strength" (IX.484-85) are expressed through in his "courage hautie" (IX.485) and physical form: "of limb / Heroic built" (IX.485-86). In contrast Eve is described in terms of the physical beauty that complements her role as an attractive companion, with undertones of eroticism: "divinely fair, fit love for gods, / Not terrible, though terrour be in love" (IX.489). Having established the attributes of the most concrete examples of male and female that appear in Paradise Lost, it now remains to establish the extent to which the angels are male, both physically and behaviourally.

It is clear that the differences between Adam and Eve are not merely physical, but instead their forms reflect the gendered roles that they are intended to play. As their forms are fixed, there is little need to distinguish between their respective physical sex and gender identity. However, as angels are composed of the morphic spiritual essence they lack a fixed physicality. This means that not only do they avoid the limitations of the human senses but they also possess an inherent ability to change their form:

All Heart they live, all Head, all Eye, all Eare,

All Intellect, all Sense, and as they please,

They Limb themselves, and colour, shape or size

Assume, as likes them best, condense or rare. (VI.350-53)

Given this mutability it follows that two attributes of sex and gender may not necessarily be aligned. For logically a spirit could choose to assume a form that differed in sex from the gender it identified with, if any: a spirit that saw herself as female could nevertheless assume the physical form of a 
male for example. Indeed this appears to be the case for some of the fallen angels, as highlighted earlier in Book II:

For Spirits when they please

Can either Sex assume, or both; so soft

And uncompounded is thir Essence pure,

Not ti'd or manacl'd with joynt or limb,

Nor founded on the brittle strength of bones,

Like cumbrous flesh; but in what shape they choose

Dilated or condens't, bright or obscure,

Can execute thir aerie purposes,

And works of love or enmity fulfill. (II.423-29)

However, this potentially changeable aspect appears in the context of describing the degrading forms of the fallen angels - the uniformly masculine appearance of the angels who remain faithful is clearly established within the text itself. That they are not female in appearance is clear, as shown within the description of Eve through the eyes of Satan where she is described as possessing a "Heav'nly form / Angelic, but more soft, ${ }^{11}$ and Feminine" (IX.457-58). Through this contrast, the angels are attributed with a form that lacks both femininity and major softness - traits we have seen associated with the femininity of Eve. Of course, the fact that the angels lack a form that is female in sex, does not in itself imply that they must be male. However Adam's following description of a uniformly masculine heaven (IX.889-90) which lacks the "novelty" of a female (IX.891), strengthens the notion that angels appear physically male; the fact that both Adam and Eve have already seen the angel Raphael in his six-winged (V.277) "proper shape" (V.276) clinches this. For when Adam first sees the angel approaching, before he has even had a chance to determine the identity of the "glorious shape" (V.309) he still refers to it as male: "he" (V.312).

But does this mean that since the angels are male by default, and choose to appear so physically, that they themselves identify as male in gender and behaviour? It would seem so. Michael, the leader of the heaven's armies (VI.44), assumes the form of a human military leader delivering his terms of truce for the "airy purpose" of delivering God's judgement after the fall: "th' Arch-Angel soon drew nigh, / Not in his shape Celestial, but as Man /Clad to meet Man" (XI.238-40). Despite the change, the form chosen by Michael is still irrefutably male and exhibits several masculine qualities: leadership, through his "militarie Vest of purple" (XI.241) which is compared to that "worn by Kings and Hero's old / In time of Truce" (XI.243-44); physical

11 The 'Oxford comma' here is significant as it separates the "feminine" adjective from the "more" comparative: meaning Eve is 'softer than the angels but also feminine', and not: 'softer and more feminine than the angels'. The latter would imply that the angels are to some degree female, though less so than Eve. 
manliness "prime / In Manhood where Youth ended" (XI.245-46); and martial prowess in bearing both the armour and weapons of a warrior, "starrie Helm" (XI.245), and a "glistering Zodiac" (XI.248) of the sword described as "Satans dire dread" and his spear (XI.249). The form that Michael chooses here reflects his role as a military commander and in doing so reveals his male identity.

A close examination of the most prominent fallen angel, Satan, reveals that he too remains physically male, and displays a similarly masculine identity to Michael. Tellingly when Satan changes from "his proper shape" (II.634), many of the various disguises that Satan adopts in his journey to Eden, from the "stripling cherub" (II.636), to the lion (IV.402) and tiger (IV.403) are not only male in appearance but also reflect masculine qualities: the young cherub's courage in adventuring alone (III.697-99), the kingly lion's “fiery glare” (IV.403), and the tiger's dangerous physicality with Adam and Eve being compared to "two gentle fawns" that he stalks (IV.403-8). The serpent that he later possesses is also clearly male as described in Book IV (347), and shares Satan's cunning (IV.349). Like Raphael, Satan's base form is also revealed to be male when his toad-like (IV.800) disguise is stripped from him:

Him thus intent Ithuriel with his Spear

Touch'd lightly; for no falshood can endure

Touch of Celestial temper, but returns

Of force to its own likeness. (IV.810-13)

Thus Satan is forced to return to his base form of a "grislie king" (IV.821); this form's physical splendour has degraded as a result of his fall to such an extent that he is no longer recognisable to the angels that find him (IV.835-40), but is nonetheless clearly male and possessing the "Regal port" of a ruler (IV.869). From this it is clear that, despite their inherent ability to "assume" different forms, even the fallen angels seem to have a true form of a definite physical sex. Satan's description here harkens back to when he first met Death at the gates of hell. Death is initially described in sexless terms:

The other shape,

If shape it might be call'd that shape had none

Distinguishable in member, joynt, or limb,

Or substance might be call'd that shadow seem'd,

For each seem'd either; black it stood as Night,

Fierce as ten Furies, terrible as Hell,

And shook a dreadful Dart (II.666-72).

But the following lines reveal that he is in fact male: "what seem'd his head / The likeness of a Kingly Crown had on" (II.672-73). Thus Death also reinforces the masculine associations of leadership, as well as martial strength. The fact that Satan was able to impregnate Sin, in conjunction 
with the fixed maleness of his base form, attributes to him a male reproductive role. As Death also impregnated Sin this implies that his base form must be similarly masculine.

Both Satan's appearance and behaviour reflect the masculine qualities of Adam. ${ }^{12}$ From the very first Book of Paradise Lost, Satan is repeatedly described as both immensely physical, "stretcht out huge in length" (I.209) and with a "mighty Stature" (I.222), but also martial: he bears an enormous shield "like the Moon" (I.287), and a spear to which the "tallest Pine" (I.292) seems "but a wand" (I.294). His confrontation with Death is an episode of epic and heroic posturing that is ended only by the intervention of Sin:

So spake the grieslie terrour, and in shape, So speaking and so threatning, grew tenfold More dreadful and deform: on th' other side Incenst with indignation Satan stood Unterrifi'd, and like a Comet burn'd, That fires the length of Ophiucus huge In th' Artick Sky, and from his horrid hair Shakes Pestilence and Warr. Each at the Head Level'd his deadly aime; thir fatall hands No second stroke intend, and such a frown Each cast at th' other... that Hell Grew darker at thir frown, so matcht they stood; For never but once more was either like To meet so great a foe: and now great deeds Had been achiev'd, whereof all Hell had rung, Had not the Snakie Sorceress that sat Fast by Hell Gate, and kept the fatal Key, Ris'n, and with hideous outcry rush'd between (II.704-14; 19-26)

The appearances of both Satan and Death here display the masculine traits of physical power, courage and martial ability. In contrast their female counterpart Sin, despite being born "arm'd" (II.757), refrains from combat and seems to instead rely solely on her feminine charm leaving her defenceless against Death's horrific pursuit. Thus Satan, Death and Sin all behave in concordance with the established gendered qualities, masculine martial power and feminine charm respectively.

These martial qualities are not just restricted to Satan and Death, but common to all the angels. The seraph Abdiel not only exhibits great courage by alone upbraiding his commander Satan about the rationale behind his intended rebellion, enduring also the scorn of his former comrades (V.804-907), but at the start of the war in heaven fearlessly strikes the towering Satan himself, sending him staggering backwards (VI.111-98). The archangel Michael proves his high 
rank by wounding Satan in single combat and Gabriel likewise defeats Moloch (355-62). Even the scholarly Raphael has a masculine physicality, having broad shoulders (V.279) like Adam's, and emulates Uriel by sending a huge rebel throne fleeing (VI.362-68). It is not only the greater angels that display courage: the "strong and suttle" Ithuriel and Zephon (IV.786) remain "unmovd with fear" (IV.822), despite their surprise upon discovering Satan.

Satan is not merely a king in name, but possesses the charisma of a leader. Like Adam, Satan was created to lead. For just as Adam's "fair large Front and Eye sublime declar'd/ Absolute rule” (IV.300-301), Satan's bright “count'nance” (V.708), and his high status in heaven (V.706-7) enable him to seduce a third of heaven's angels into open rebellion (V.708-10). Even after the failed rebellion, Satan's leadership over those that followed him is not shaken: despite their pain (I.33536) they respond quickly "to thir Generals Voyce" (I.337). The angels that remain faithful also exhibit leadership qualities as appropriate to their position in the heavenly hierarchy. One example already mentioned is that of Michael as the overall leader of heaven's military, who with Gabriel leads forth the other angels against Satan's rebel forces (VI.44-46). It is the latter who is later charged with the protection of Eden as "Chief of th' Angelic Guards" (IV.550).

However, from Raphael's description of the war in heaven, we learn that each of the individual angels display in abundance the masculine qualities of military prowess, leadership, and courage. Each possesses the martial ability of an entire legion (VI.231-32), the tactical leadership of a general (VI.232-36), and complete fearlessness (VI.236-38):

As each divided Legion might have seemd

A numerous Host, in strength each armed hand

A Legion, led in fight, yet Leader seemd

Each Warriour single as in Chief, expert

When to advance, or stand, or turn the sway

Of Battel, open when, and when to close

The ridges of grim Warr; no thought of flight,

None of retreat, no unbecoming deed

153 That argu'd fear; each on himself reli'd (VI.230-38)

In his conversations with Adam, Raphael shares in the first man's "contemplation" (IV.295) by both describing to him in detail events such as the war in heaven (V.562-VI.912) and the creation of the world (VII), and reciprocates by listening to Adam's own account of his creation (VIII.250ff). Satan shows a similar capacity for reflection early in Book IV when he muses upon his rebellion:

yet all his good prov'd ill in me,

And wrought but malice; lifted up so high

I sdeind subjection, and thought one step higher

Would set me highest, and in a moment quit

The debt immense of endless gratitude, 
So burthensome still paying, still to ow; Forgetful what from him I still receivd, And understood not that a grateful mind By owing owes not, but still pays, at once Indebted and dischargd; what burden then? (IV.48-57)

Satan applies this formidable intellect to aid in his secret invasion of Eden. Cunningly disguised as a lesser angel he even tricks the sharp-sighted Uriel into showing him the location of Eden for "neither Man nor Angel can discern / Hypocrisie, the onely evil that walks / Invisible, except to God alone" (III.682-84). When he later finds that his assumed disguises can be removed by the "Touch of celestial temper" (IV.812), Satan overcomes this weakness by possessing the serpent and then draws upon its own cunning nature to seduce Eve.

Unfortunately for Satan, he is not the only one skilled in reason. Working within each of their assigned roles, various angels each employ their various talents intelligently to ultimately catch him. Uriel, despite being initially fooled by Satan's disguise, through his keen vision sees the latter's complexion changing with emotion and doubt (IV.114-30) and from this reasons that he is not who he seems, and immediately warns Gabriel. Gabriel in turn acts upon this information by sending Ithuriel and Zephon to investigate the garden. Then it is Ithuriel that displays initiative by disrupting the disguise of Satan which results in his apprehension. Thus each of these angels performs their duty with not only military precision, but with the other masculine qualities of contemplative reasoning, leadership and courage. From this we can see that the male appearance of the angels is a reflection of the masculine elements that comprise their role and purpose in the hierarchy of heaven, just as Adam's physical form reflects the masculinity of his role in contrast to the femininity of Eve in their respective gendered purposes.

Interestingly the fallen angels, when left by Satan to their own devices, display many of the masculine tropes associated with their former roles in heaven:

the ranged powers

Disband, and wandring, each his several way

Pursues, as inclination or sad choice

Leads him perplext, where he may likeliest find

Truce to his restless thoughts, and entertain

The irksom hours, till this great Chief return. (II.522-27)

These fallen spirits thus engage variously in military exercises (II.528-38), feats of strength (II.53946), pastoral performances (II.546-55), philosophical contemplation (II.555-69), and scouting parties (II.570 ff). As well as reflecting their previous roles in heaven, their behaviour here also reflects many of the masculine traits, also displayed by the faithful angels; consider the physical exercises of the Gabriel's troops as they wait for their night duty: 
Betwixt these rockie Pillars Gabriel sat

Chief of th' Angelic Guards, awaiting night;

About him exercis'd Heroic Games

Th' unarmed Youth of Heav'n, but nigh at hand

Celestial Armourie, Shields, Helmes, and Speares,

Hung high with Diamond flaming, and with Gold. (IV.549-54)

It seems clear from these examples that, in addition to being physically male, the fallen angels identify with the masculine aspects of their roles to the extent that left to their own devices they still exhibit similarly masculine behaviour.

We have now established that the angelic spirits, though they lack the fixidity of a structured male body like Adam's, share many of the first man's male qualities: in both the male physique of the base form and their masculine personal gender identity - this physical masculinity reflects the masculine qualities of the purpose for which they were created. Now it remains to examine how they function in terms of their pastoral society in Paradise Lost, and how sexuality and desire are approached in other Miltonic texts, before we look at how their desires are actualised through their physical intimacy. 


\section{Chapter Three: Pastoral Portrayals}

In Paradise Lost, Milton's angels are often presented in a manner that bears much resemblance to the tropes classical pastoral and its use in his other pastoral poetry. Before entering into a closer analysis of the passage on the angels' sexuality, we need to first look at the wider implications of this pastoral portrayal of Milton's heaven and its angelic inhabitants: the closed and uniformly masculine society, the close and private relationships within this setting, as well as the erotic possibilities associated with the genre.

Milton's use of pastoral elements in his portrayal of heaven has been established by John R. Knott Jnr., and more recently Lewalski. While much of the angels' militarism, and the structure of the poem itself, draws upon the tropes of classical epic poetry, the private life of the angels resonates with pastoral; the title of the poem could indeed describe the fallen angels' loss of the paradise that is heaven, as much as it describes mankind's loss of Eden.

In Paradise Lost, the angels are all portrayed as masculine beings forming what we could now call an exclusively male homosocial society. The term homosocial was appropriated by Sedgwick, in her book Between Men: English Literature and Male Homosocial Desire, to describe a broad spectrum of same-sex relationships including, as a subset, those of a homosexual nature(1-2). The uniformly masculine nature of this angelic society parallels that of Milton's own society. For, as is well appreciated, Renaissance England was very much primarily a male-dominated society. Bruce R. Smith argues, in Homosexual Desire in Shakespeare's England, that there was now a "sense of homogeneous national culture among the English ruling class. And part of that homogeneity was its maleness" (83). Not only did this class have its own culture but it also had its own language and secrets; Latin was "the tribal language of educated men. As a male code, Latin was the language of law, diplomacy, and international trade. It was also the language of sexual knowledge” (83). Smith's focus is on Shakespearian England and as such his timeframe seems to vary - extending occasionally into the next century - but many of his observations seem to have carried over into Milton's time.

The angels, despite having the ability to change their physical sex, all seem to share a homogeneous masculine identity, and are described as such by Adam. For the first man, in frustration at Eve's fall, and his own, asks why God created the "fair defect" (X.891) that is his female companion, rather than populating the world immediately with nothing but men, as he had heaven (X.889-90) when he created the "angels without feminine" (X.893), or even finding "some 
other way to generate / Mankind?” (894-95). For Adam finds that he is able to relate to the angels who share the masculine qualities of his gender identity.

To describe anyone living in Early Modern England as being a "homosexual" would be an anachronism. Even though such an identity did not exist, one would be extremely naive to think that homosexual activity did not exist. Thus for the purposes of this thesis, homosexual, and the following terms will be used solely in their adjectival forms rather than as nouns. It seems pertinant here to draw a distinction between what is meant by homosexual as opposed to homoerotic homosexual is more concrete, referring to same-sex sexual activity, whereas homoerotic describes an erotic desire for the same sex; homoerotic attraction has the potential to lead to homosexual action, but may not be actualised as such. The fourth term of relevance here is homoplatonic, coined by George Rousseau to describe "a complex set of arrangements primarily evident in samesex discipleship and tutelage, and the friendships and other licit and illicit relations arising from these arrangements and these cultural practices" (20). As homoerotic describes desire it is subjective and thus hard to define, lacking the social and physical elements of homoplatonic and homosexual, respectively. All three terms fall under the homosocial umbrella.

Each of these terms describes an aspect of masculine culture occurring in Milton that I wish to examine: the broader homosocial context of the male institutions, the homoerotic associations of pastoral, the educational nature of the friendship pairings within this society, and the homosexual relations posited by some critics.

A critical example of the various points on this spectrum can be seen in the works of Alan Bray, whose seminal work, Homosexuality in Renaissance England, in 1982 helped open the doors of queer literary criticism. He saw sodomy as being a political issue, representing a disruption of order (14-16). Bray argued that homosexual acts existed quietly within the Early Modern context as evidenced by the low incidence of sodomy trials; the need for sexual release coupled with the late age of marriage, condemnation and punishment of premarital sex and close proximity of men meant that homosexual acts was an attractive and practical option for the unmarried man (47).

Similarly, Smith argues that the young men who would become the ruling class reached maturity in exclusively male social institutions that provided a breeding ground for homoerotic tension: "Schools, colleges, and the inns of court were households in both the literal and figurative senses of the word: young men studied together, played together, ate together, and, like everyone else in the sixteenth century, slept together two to a bed" (84). Smith highlights here the intimacy enforced by this masculine homosocial culture in which such a youth would be immersed:

He was removed from his mother and home at an early age to an all-male environment; he came to maturity in an all-male household [sic] that had a sharp sense of its own identity, its own 
traditions, even its own language; he married at what, for us, would be a late age, a full ten to fifteen years after sexual maturity; and he had extremely limited sexual access to women of his own age and class because of the high premium placed on female virginity. (84)

For like Bray, Smith argues that within such an isolated, masculine context it would be expected that there would be some simmering homoerotic attraction: "If an anthropologist were to tell us these things about a society in the Antipodes, what conclusions would we draw about the sexlife [sic] of a youth in that society?" (84). For Smith the most telling (indirect) evidence of this homoerotic desire is "found in the poetic discourse of pastoral" (85). Milton lived in the next century but it seems that many aspects of this masculine homosociality endured through to his own upbringing, considering his educational upbringing, and that he was thirty-five at his first marriage to the young Mary Powell.

Milton had earlier drawn upon the pastoral genre, established by classical poets such as Theocritus and Virgil, to reflect this Early Modern male culture in his earlier poems 'Lycidas' and 'Epitaphium Damonis'. For as Smith points out "the pastoral scenario presents a perfect homolog[ue] to the all-male social institutions that nurtured sixteenth- and seventeenth-century males from boyhood to manhood", institutions such as Oxford or Cambridge University or one of the London Inns of Court (82). This is because, like these English institutions, the landscape of classical pastoral is masculine: "Nymphs like Nais and Amaryll may be glimpsed in the distance, but Virgil's spokesmen are without exception male” (82). In 'Lycidas', the same observation can be applied as, while female figures appear in the background in the form of muses and nymphs, the speakers in the poem are all male. In addition, these male speakers are often embodiment of male institutions: St Peter represents the church. In this poem, Milton's setting is analogous to the homosocial community of Cambridge University, also represented by the personification of the river Cam. In "Damon's Epitaph" he makes a similar parallel when describing the Italian community he engaged with in his tour of Europe. Just as Smith points out, while female figures appear in these poems, they do so in the background and lack any speaking role. Thus the element of pastoralism running throughout Milton's works is reflective of his own historical context.

But it is not only the human societies that the pastoral metaphor is used to describe; in “Comus" (4, 974-1002), "Lycidas" (174-77), and "Damon’s Epitaph" (215-219), Milton draws on pastoral to describe the respective heavens in terms of beautiful natural settings.

Bray's views on the complexity of Renaissance homosociality continued to evolve, however - as evidenced by his article "Homosexuality and the Signs of Male Friendship in Elizabethan England" where he defended apparently homoerotic acts of affection as being merely the actions 
of platonic friends (3-8). This article was incorporated into his later work The Friend which examined the institution of formal friendship in Early Modern England as evidenced by the existence of various memorial inscriptions from throughout the period. So it seems that Bray has moved along the spectrum of homosociality, from homosexuality to the problems of homoeroticism, to that of idealised male friendship.

An example of the complex nature of Renaissance homosociality is the homoplatonic relationship between Roger Ascham and John Whitney. Roger Ascham reveals in the second book of his Scholemaster, as an example of the efficiency of his teaching method of double-translation, that he once read Cicero's De Amicitia with his bedmate, a young John Whitney:

Iohn Whitneye, a yong ientleman, was my bedfeloe, who willyng by good nature and prouoked by mine aduise, began to learne the Latin tong, after the order declared in this booke. (84)

Smith drily observes that here "the text - pre-, sub-, and actual - was de Amicitia" (84), highlighting the homoerotic potential in such a situation. Alan Stewart also cites this episode in his Sodomy and Interpretation as an example of his structured literary friendships, considering the subject matter of the text that they were reading together. As Stewart states:

The shared bedchamber, the shared book, and of course the choice of text place the scene firmly within the realms of Ciceronian amicitia: as such it is only one of countless sixteenthcentury accounts of male friendship, stretching from Erasmus, Colet, and Elyot to Lyly, Shakespeare and Bacon (126).

Smith highlights the connection of Whitney with Nicholas Udall, headmaster of Eton, who was convicted of sodomy with some of his students as one of the few possible examples of homoerotic activity though he himself admits that there is "very little direct evidence" (84),

The close relationship between Milton and Charles Diodati has attracted claims of homoeroticism, starting with Shawcross in 1975, and more recently with Guy-Bray. Other critics, such as Boehrer, Chaplin and Raymond have argued that this relationship was one of the primary influences on Milton's advocacy for companionate marriage in his divorce tracts.

The Latin poem "Epitaphium Damonis" or "Damon's Epitaph" is one of Milton's most personal works in which he expresses his grief at the loss of Charles Diodati who had been his friend since childhood. Like "Lycidas", the epitaph encodes the historical reality within a pastoral setting. Unlike in the earlier poem however, here Milton spells out the conceit in the preface, aligning himself with the shepherd Thyrsis and Diodati with Damon. Cicero uses a similar method in his de Amicitia, one of the foremost texts in Renaissance England, which is framed as a letter to his friend Atticus where he states that he will encapsulate his thoughts on the virtues of their friendship within an account of the historical Laelius's famous friendship with Scipio Africanus: 
"In reading all that [Laelius] says about friendship, you will recognize the picture of your own friendship for me" (Cicero 1). A comparison between these two texts will be useful in establishing the extent to which the friendship of Milton and Diodati adhered to this classical model.

In the epitaph Milton also explores various aspects of the nature of a friendship that shares many aspects of the Renaissance idealised friendship, of which de Amicitia was one of the foremost influences. Like Cicero's Laelius, Thyrsis comments on features relating to a close friendship such as companionship, love, death, virtue and immortality.

While Cicero peppers his account with historical references and places it in the form of a dialogue to strengthen the realism of his work (1), Milton draws upon the classical tradition of such poets as Theocritus and Virgil as seen by his invocation of Hylas and Daphnis at the start of the poem, both of whom are the subjects of dirges sung by shepherds in the Idylls (Theocritus I; XIII); there is a lament for Daphnis also in Virgil's fifth eclogue. Modelled on these pastoral origins, here Thyrsis laments the loss of his friend Damon:

Nymphs of Himera - for you remember Daphnis and Hylas and
the long lamented fate of Bion - repeat this Sicilian song through
the cities of Thames; tell what words, what murmurs, unhappy
Thyrsis poured forth, and with what ceaseless complaints he
disturbed the caves, the rivers, the eddying fountains, and the
recesses of the groves, while he mourned to himself for Damon
snatched away, nor left deep night free from his lamentations as he
wandered in lonely places. Twice the stalk had risen with green
ear, and as often had the garners counted the yellow crops, since
his last day had borne Damon down to the shades, and Thyrsis
was not there the while (1-12).

Interestingly the shepherd who sings the lament for Daphnis in Theocritus's first idyll is also called Thyrsis, so when Milton adopts this name to assert that Damon will be "next after Daphnis" in receiving the praises of the shepherds, he is creating a continuation of the pastoral context, and also reinforcing his alignment with his classical shepherd namesake Thyrsis who outstripped "All others in herdsman's song" (I.20).

The poem itself is broken up by a repeating refrain, similar to the pastoral models - but unlike the originals which often changed, at least in tense, as the poem progressed, here it is unchanging and reflects the paralysing effects of grief: "Go home unfed, my lambs, your troubled master is not free to tend you" $(18,26,35$, etc). Thyrsis is so overwhelmed with grief that he is unable to fulfil his responsibility in caring for his flock; the disappearance of the refrain from the final thirty-nine lines of the poem reflects Thyrsis's final acceptance of his loss. Laelius reflects back positively on his memories of his friendship with Scipio:

But I so enjoy the memory of our friendship, that I seem to have owed the happiness of my life to my having lived with Scipio, with 
whom I was united in the care of public interests and of private affairs, who was my companion at home and served by my side in the army and with whom-and therein lies the special virtue of friendship-I was in perfect harmony of purpose, taste, and sentiment (Cicero 4).

In contrast, Milton's Thyrsis is distraught and depressed over his loss which may be a result of the contrast the perspectives of the young and old, but may also reflect the different foci of the poems: Milton's is written in mourning whereas Cicero's is portrayed as occurring after the event, and a reflection on the friendship rather than the loss. The writers may also may be influenced by their historical context, Cicero's philosophical acceptance may be due to the fact that, unlike Laelius's loss of Scipio, the friend to whom he addresses de Amicitia was still alive; Milton is writing about a friend he has lost.

In the last passage of the Amicitia, Laelius sums up the nature of his friendship with Scipio:

We had one home; the same diet, and that simple; we were together, not only in military service, but also in journeying and in our rural sojourns. And what shall I say of our unflagging zeal in the pursuit of knowledge, and in learning everything now within our reach, - an employment in which, when not under the eyes of the public, we passed all our leisure time together? (Cicero 27)

The above passage could almost be used to describe the closeness of the relationship between Thyrsis and Damon as depicted in the epitaph. Thyrsis does not explicitly state that he and Damon share a home, but shows a similar intimacy when he reveals that they regularly share evenings together when he exclaims: "Who will now lull my day to rest with talk and song?" (153) then expands this into a heart-warming, and -wrenching, description of nightly companionship and its loss:

To whom may I entrust my heart? Who will teach me to assuage my gnawing cares and to cheat the long night with pleasant conversation, when the mellow pears hiss before the cheery fire, nuts crackle on the hearth, and outside the stormy south wind is throwing all in confusion and comes roaring through the elms. $(45-49)$

Note here the sharing of simple food, as mentioned by Laelius. This emphasis on companionable eating is reflected in passages of Milton's later works such as the Son dreaming of sharing meals with prophets in Paradise Regained (II.277-78) and Adam with Raphael in Paradise Lost (PL V.433449).

The pastoral setting, through its withdrawal from civilisation, removes those in the epitaph from the context of the public eye and military service. But like Laelius's description of sharing in 
the dangers of military service with Scipio, Thyrsis describes sharing similar dangers with Damon, such as enduring the elements to defend their flocks from wild animals:

But what will become of me; what faithful friend will stay close by my side as you were wont to do in bitter cold through places rough with frost, or under the fierce sun with the grasses dying from drought, whether the task were to go within spear's throw of great lions or to frighten the ravenous wolves from the high sheep folds? (37-42)

So, like Laelius and Scipio in their military service, Thyrsis and Damon braved dangers together throwing spears at lions and chasing away wolves.

The pastoral setting might be expected to exclude any sort of scholarly learning, but nevertheless there is included in the epitaph an example of learning together, albeit in a tutorstudent relationship. For Thyrsis's mentions how when away in Italy, he still imagined spending time with Damon not knowing him to be already dead:

Say, good friend, are you free? If nothing prevents us, let us go and lie down a while in the murmuring shade, by the waters of Colne, or in the fields of Cassivellanus. You shall tell me of your healing herbs and juices, hellebore, the lowly crocus, and the leaf of the hyacinth, whatever plant the marshes yield, and tell me of the physician's art (147-152).

He describes an idyllic scene of relaxation, amongst which Damon would instruct him on the medicinal uses of various plants, reflecting Laelius's comments on the mutual love of learning he shared with Scipio. The inclusion of the hyacinth here could be seen as ominous, due to its associations with the death of the lover of Apollo. Milton had used a similar concept earlier in "Comus", where his Attendant Spirit, in the guise of a shepherd, justified his knowledge of a magical protective herb by describing his relationship with another shepherd who had taught him about herbs in exchange for singing:

Brought to my mind a certain shepherd lad Of small regard to see to, yet well skilled In every virtuous plant and healing herb That spreads her verdant leaf to the morning ray, He loved me well, and oft would beg me sing, Which when I did, he on the tender grass Would sit, and hearken even to ecstasy, And in requital ope his leather scrip And show me simples of a thousand names Telling their strange and vigorous faculties (619-628)

In both scenes the reality of the experience is uncertain. But from the detailed nature of the description in the epitaph, however, it is likely that Thyrsis had already experienced such learning from Damon. The Attendant Spirit in "Comus" has only assumed the disguise of a shepherd; it is 
unclear how much he is fabricating in his story, how much he knows about the specific shepherd, also called Thyrsis (494), whose form he is assuming, and how much he is drawing from his own heavenly relationships. In the epitaph, however, it is clear that Milton is alluding to Diodati's own medical studies, which it appears he may have discussed with Milton.

As Thyrsis and Damon would spend the evening together in companionship, so too they do the summer day:

Or in summer when the day turns on mid-axle, when Pan takes his sleep hidden in the oak shade, and the nymphs return to their wonted seats beneath the waters, when shepherds lie concealed, and the husbandman snores beneath the hedge, who will then bring back to me your blandishments, your laughter, Cecropian wit, culture and charm? (51-56)

The description of the "husbandman" snoring is something that invites the sort of wit that Thyrsis is attributing to Damon. Here Thyrsis also displays an example along the lines of the "perfect harmony of purpose, taste, and sentiment" that Laelius attributes to his relationship with Scipio. The scene is a pastoral one of rest and relaxation.

Thyrsis also draws comparisons with the animal world to highlight the uniqueness of his lost friendship:

Ah me! how like one another are the young cattle that frolic through the fields, all comrades to each other under one harmonious law; none seeks from out the herd a special friend. Even so the jackals come in packs to their food, and the shaggy wild asses by turn are joined in pairs. The law of the sea is the same, where on the desert shore Proteus numbers his troops of sea-calves. (94-100)

Thyrsis here is highlighting the communal nature of the animals, with their lack of individual relationships within the herd. He refers to the sparrow as an example of an animal that does have a singular companion, but points out how easily it is replaced, in contrast with the rarity of true human companionship:

Even that paltry bird the sparrow always has a mate with whom it happily flies about to every heap of grain, and returns at evening to its own thatch; yet should chance strike one of them dead whether the kite with hooked beak has brought this fate, or the clown has pierced it with his arrow - the other seeks a new mate to be henceforth its companion in flight. But we men are a stony race, a tribe vexed by stern fates, alien in our minds one from the other, in our hearts discordant. Hardly from among thousands does one find a single kindred spirit, or if fortune not unfriendly gives one such in answer to our prayers, yet in a day and an hour when we least expect it he is snatched away leaving an everlasting wound. (100-111) 
Laelius approaches the same theme of the rarity of true friendship but in a more positive light:

I am not now speaking of the common and moderate type of friendship, which yet yields both pleasure and profit, but, of true and perfect friendship, like that which existed in the few instances that are held in special remembrance. (6)

In both these works much is made of the virtuous nature of the deceased companion, in association with ascension and love. In the preface to the poem, Milton highlights the virtue of Diodati:

Under the guise of Damon is here understood Charles Diodati, connected on his father's side with the Tuscan city of Lucca, otherwise an Englishman, a youth distinguished while he lived for genius, learning, and other most notable virtues.

Likewise, Cicero considers virtue to be integral to this ideal of friendship:

Virtue, I say to you, Caius Fannius, and to you, Quintus Mucius,virtue both forms and preserves friendships. In it is mutual agreement; in it is stability; in it is consistency of conduct and character. When it has put itself forth and shown its light, and has seen and recognized the same light in another, it draws near to that light, and receives in return what the other has to give

Here we have similar connection to the "kindred spirit" of the epitaph, which Cicero then uses to explore the ambiguity and connected nature of friendship and love:

...from this intercourse love, or friendship,- — call it which you may,- -is kindled. These terms are equally derived in our language from loving; and to love is nothing else than to cherish affection for him whom you love, with no felt need of his service, with no quest of benefit to be obtained from him; while, nevertheless, serviceableness blooms out from friendship, however little you may have had it in view. (27)

Milton uses a similar obliquity within the epitaph in his references to love. Mopsus, described as being "versed in the stars and the language of birds" (153), realises something is amiss, guessing that Thyrsis is either lovesick or under the influence of a malevolent star:

"What is this, Thyrsis?" said he; "What black melancholy is tormenting you? Either you are wasting with love, or some star is casting an evil spell over you. Saturn's star has often been baleful to shepherds, and his leaden shaft has pierced your inmost breast." (77-80)

While Mopsus seems to go with his second conjecture, judging by his expanded commentary, the first could be seen as not that far off from what Thyrsis is experiencing. For here similarly to Cicero/Laelius's blurring the lines between friendship and love, Thyrsis is mourning the loss of 
Damon as if he were a departed lover. This observation makes the following commentary of the “amazed" (155) nymphs more poignant:

What will become of you, Thyrsis? What do you wish? The brow of youth is not commonly cloudy, the eyes stern, the mien austere; youth seeks dances and nimble sports, and always love as its right. Twice wretched is he who loves late. (82-86)

For in a way Thyrsis is one who has loved too late, as he was absent when his friend died and now regrets his absence. Both Mopsus and the nymphs seem unaware of Damon's death, which reflects the reality of Thyrsis's loss: Damon had died two years before his friends returned so it is not surprising that Mopsus and the nymphs fail to connect this delayed grief with its subject. The last mention of love occurs near the end of the poem within a description of the engravings on a pair of cups:

Here too is Love, his quiver, flashing arms, and torch, his darts tipped with fiery bronze, all pictured in a cloud. He does not aim at little souls and the ignoble hearts of the rabble, but, rolling his flaming eyes about, unwearied he ever scatters his missiles on high through the spheres, and never aims his shots downward. Hence minds immortal and forms divine are inflamed with love. (191-97)

Here Cupid is portrayed as blindly scattering his arrows through the heavens, avoiding the "rabble" on earth and instead hitting eternal minds and gods and causing them to love. Through the contrast this seems similar to Cicero's concept of the light of virtuous people attracting each other, just as those virtuous in mind or form struck by Cupid's arrow are drawn to others. This is reinforced by Thyrsis's immediate realisation that Damon, due to his virtue, will have ascended to the heavens,

You too are among these, Damon - nor does elusive hope deceive me - surely you too are amongst these; for whither should your sweet and holy simplicity retire, whither your spotless virtue? It is wrong to seek you in Lethean Orcus. Tears become you not, and I shall weep no more. Away then tears! (198-203)

rather than the alternative of joining the "obscure shades" (22) and "whole base herd of the silent dead" (25). Laelius sees the same alternative and comes to similar conclusion:

from so high a grade of honour [Scipio] seems to have passed on into the assembly of the gods rather than to have gone down into the underworld (3).

Along with the immortality of the soul, Laelius too attributes the ascension to heaven as a reward for virtue:

If it is true that the soul of every man of surpassing excellence takes flight, as it were, from the custody and bondage of the body, to whom can we imagine the way to the gods more easy than to Scipio? (4). 
In the final passage of the epitaph Damon/Diodati, like Scipio, is seen as being elevated to the realm of the gods, rather than sent down to Hades (Amicitia 3). Subtly presented as the description of the two Cups from Manso (181-84) - a description common to classical pastoral poetry - is a depiction of Cupid (191-97), but it is preceded by a scene strongly connected with resurrection and ascension:

In the middle are the waters of the Red Sea and the odoriferous spring, the far off coasts of Arabia and the trees dropping balsam, amidst these the phoenix, divine bird, alone of its kind on earth, gleaming blue, with wings of many colours, watches Aurora rise over the glassy waves (185-89).

Here we have the phoenix, a mythical bird which would be reborn from death, alongside the symbolism of a rising sun out of water, both symbols of rebirth and ascension. The water itself is associated with fates of both Hylas and Daphnis, to whom the poem alluded at the start, and both of whom achieved some sort of immortality through their death:

Damon dwells in the purity of heaven, for he himself is pure. He has thrust back the rainbow with his foot, and among the souls of heroes and the everlasting gods he quaffs the heavenly waters, and drinks of joys with his sacred lips. (193-207)

In both works, the speaker reconciles the loss of their friend by stressing the eternal nature of their friendship. For Thyrsis, the friendship is literal upon realising the actuality of his friend's ascension:

But now that the rights of heaven are yours, stand by my side and gently befriend me, whatever be now your name, whether you would still be our Damon, or whether you prefer to be called Diodati, by which divine name all the dwellers in heaven will know you, but in the forests you will still be called Damon. (207-11)

For Laelius, the friendship continues on his memory and that of those around him:

For me indeed, Scipio, though suddenly snatched away, still lives and will always live; for I loved the virtue of the man, which is not extinguished. Nor does it float before my eyes only, as I have always had it at hand; it will also be renowned and illustrious with generations to come. No one will ever enter with courage and hope on a high and noble career, without proposing to himself as a standard the memory and image of his virtue. Indeed, of all things which fortune or nature ever gave me, I have nothing that I can compare with the friendship of Scipio. In this there was a common feeling as to the affairs of the State; in this, mutual counsel as to our private concerns; in this, too, a repose full of delight. Never, so far as I know, did I offend him in the least thing; never did I hear from him a word which I would not wish to hear (27). 
Laelius also says that the memories of his experiences with Scipio bring him comfort, seeing their parting is only temporary:

Had the recollection and remembrance of these things died with him, I could not anyhow bear the loss of a man, thus bound to me in the closest intimacy and holding me in the dearest love. But they are not blotted out, they are rather nourished and increased by reflection and memory; and were I entirely bereft of them, my advanced age would still be my great comfort, for I can miss his society but for a brief season, and all sorrows, however heavy, if they can last but a little while, ought to be endured (Cicero 27).

The major textual obstacle in the epitaph that any critic would have to overcome when arguing for homosexual relations between Milton and Diodati is the emphasis on Damon/Diodati's innocence and virginity near the end of the poem:

Because a rosy blush, and a youth without stain were dear to you, because you never tasted the pleasures of marriage, lo! for you are reserved a virgin's honours (212-14).

The final passage is a vision of heaven that is a fusion of pastoral elements, such as the wreath and dancing, as well as invoking the biblical, Christian imagery of the metaphorical marriage:

Your noble head bound with a glittering wreath, in your hands the glad branches of the leafy palm, you shall for ever act and act again the immortal nuptials, where song and the lyre, mingled with the blessed dances, wax rapturous, and the joyous revels rage under the thyrsis of Zion. (215-19)

It is clear that Milton's depiction of his friendship with Charles Diodati, within the pastoral landscape of the epitaph, reflects the Renaissance ideal of homosocial friendship as epitomised in de Amicitia.

However such a friendship due to its intimate nature could easily conceal, and include, a homosexual element, if the men shared a same-sex attraction. Thus Shawcross in 1975, and more recently Guy-Bray, are able to argue for a homosexual attraction between Milton and Diodati.

While the weight of both their arguments is focused on sexual imagery appearing in the final lines of the poem, Guy-Bray also joins Boehrer in noting the classical sexual associations of the animals in Milton's catalogue to which he compares the restricted loneliness of the human condition. Shawcross introduced the idea that the sexual imagery in the poem reflects a historical homoerotic tension between the two men, an argument that Guy-Bray partially adopts to support his overall premise that the elegy was used as a vehicle to express homosexual relationships. He and Boehrer also view the epitaph as a turning point for Milton as a writer from the pastoral genre to that of epic. 
With this in mind, let us return to Paradise Lost to take a closer look at the pastoral society of heaven. In Book XI all of the angels are summoned to an audience with God and the Son:

Th' Angelic blast

Filld all the Regions: from thir blissful Bowrs

Of Amarantin Shade, Fountain or Spring,

By the waters of Life, where ere they sate

In fellowships of joy: the Sons of Light

Hasted, resorting to the Summons high,

And took thir Seats; till from his Throne supream

Th' Almighty thus pronouncd his sovran Will. (XI.76-83)

From this brief description we learn that many of the angels have been at rest, scattered throughout the vast expanse of heaven - the vastness of which we catch a glimpse of in Raphael's description of the landscape that the rebel angels traverse, from the mount where they had been assembled, to their leader's palace for a council of war (V.744-60).

These beautiful natural settings fit the definition of the pastoral locus amoenus - literally meaning 'delightful place'; in his discussion of pastoral poetry, Bruce R. Smith describes this idealised natural setting appearing within pastoral poetry:

Encountering it again and again in classical, medieval, and

Renaissance literature, philologists have given this local habitation

of heart's desire a name: the locus amoenus. To the Elizabethan

imagination it was a place charged with erotic feeling, a place

where being in love and composing eclogues about being in love

are mankind's only concerns. (81-2)

Similarly, the rustic shepherds of pastoral are generally depicted as participating in what could be termed mutual "fellowships of joy". But the character of these "fellowships" is unclear. Some critics have interpreted it as a sexual euphemism; according to Empson the angels indulge in "cosy interpenetration" while off duty (107).

However, as with Raphael's description of the angels' sexuality, the description here is general and lacks any overt specificity regarding the individual spirits or their relationships. Milton's ambiguity in both these cases may be intentional, as it would be congruent with the ambiguous allusion to angelic sexuality in the New Testament; Jesus states that those who rise from the dead will not marry, and that they will be immortal like the angels (Luke 20:35-36). But given the pastoral elements, as well as the range of behaviours that the newly fallen angels exhibit in Book II when left to their own devices, it seems more likely that the general nature of these joyful fellowships reflects a variety of activities which may indeed include sexual activity - but not exclusively. For Adam and Eve also have a "blissful Bower" (IV.690) which not only provides a setting for their sexual activity, but also sleeping, shaded relaxation (V.299-302), preparing meals, eating and entertaining their visitors - such as Raphael. Considering the many parallels that Milton makes 
between the humans and angels, it seems that the bowers of the angels likewise allow their inhabitants a degree of separation from the multitude of their fellows where they may enjoy sexual relations, sleep, relax, eat and socialise with visitors.

In Paradise Lost, Raphael and Adam share a type of learning friendship - Raphael has been sent to instruct Adam, "as friend with friend" (V.229) on the dangers that face him. It seems that Adam also shared a similar friendship with God, for at the start of Book IX Milton laments that:

No more of talk where God or angel guest

With man, as with his friend, familiar used

To sit indulgent, and with him partake

Rural repast, permitting him the while

Venial discourse unblamed... (IX.1-5)

This learning friendship of Adam and Raphael (and God) has a parallel in the Renaissance relationship between the scholar and the patron; Stewart focuses on the rise of the humanist scholar and the learning relationships with their patrons formed by this new social movement that changed the landscape of English society during the Renaissance period:

The aim of humanism... was to establish itself as a required profession by deliberately juxtaposing itself to what it presented as a flawed dominant order, whose lacks it could supply. Drawing on familiar images - the hearty hunting, hawking nobleman with a taste for learning and an antipathy toward learning, and the solitary knowledge-driven scholar - the humanist aimed to enter the service of the noble patron by utilizing his textual and linguistic skills to provide a service that the patron could not provide for himself. As this pattern of patronage took hold in the sixteenth century, the humanists wrote discourses and books which recorded the shift in their social position, shifts which eventually became inscribed as English history. (Stewart xxi)

In these "knowledge transactions", Stewart argues, between humanist scholar and patron there is ... a double ethic of similitude and friendship. The two are inextricable: friendship cannot exist except between equals, and where social equality is lacking the intellectual equality or equality of learning takes its place. / English humanism, then... is premised on notions of social relations and transactions."(xxvii)

Despite their different roles and statuses Adam and Raphael, and presumably the other heavenly guests, meet as equals within Adam's bower. The relationship, like that of the scholar and the patron, is driven by outside factors and mutually beneficial. But learning also plays a part in the pastoral friendships appearing in 'Lycidas' and 'Epitaphium Damonis', and 'Comus'.

Thus, through this use of pastoral allusion, it seems that the angels in Paradise Lost, when relaxing from their duties, inhabit a society not too dissimilar from the homosocial institutions of Milton's own historical context. It seems that with the angels the homoerotic tensions within these 
societies, due to the lack of heterosocial contact, are actualised and justified through the rational purity of their mutual sexuality. 


\title{
Chapter Four: Classical Bi-Eroticism
}

\begin{abstract}
Although we typically think in terms of a dichotomy between homosexuality and heterosexuality, and between the homosexual and the heterosexual, with vague compartments for bisexuality and bisexuals, the range of human sexual response and behaviour is actually far less restricted than these artificial classifications suggest... Some people repeatedly participate in same-sex activities without ever defining themselves as homosexuals, while others define themselves as homosexual without ever participating in homoerotic activities. Because human sexual behaviour and emotions are fluid and various rather than static or exclusive, Kinsey and other students of sexuality have argued that the terms homosexual and heterosexual should more properly be used as adjectives rather than nouns, referring to acts and emotions, but not to people. (Summers 2).
\end{abstract}

Recent research in the field of psychology has confirmed the existence of male bisexuals who are not only attracted to both sexes but have a greater degree of sexual attraction to both sexes simultaneously (Rosenthal; Cerny and Janssen). This is interesting as it seems that often in Milton's writings passages which appear to contain homoerotic imagery also contain attractive female figures. To assist in this analysis, I will now adopt the hetero- and bi-prefixes as alternatives to homoin our homosocial terminology: forming heterosocial, bisocial and so on.

Such instances occur within his Elegies. In the first, the necks of the beautiful women Milton is describing are compared to the arms of the classical hero Pelops (57), and their cheeks compared with both hyacinthine purple (alluding to Hyacinth, former lover of Apollo) and Adonis's flower (Adonis being the attractive male lover of Venus) (61-62). In Elegy IV, written to his former tutor Thomas Young, Milton compares their relationship to classical homoplatonic male relationships: Socrates and Alcibiades (23-24), Aristotle and Alexander (25-26), Phoenix, Chiron, and Achilles (27-28n), each of which bear some degree of homoerotism. Later though, Milton uses heteroerotic imagery by casting himself in the role of Odysseus apologising for his late letter to his wife Penelope (55-56). In Elegy V, Apollo wears laurels in honour of his lost Daphne (13-14), and is wooed by a sensual Earth (53-60) whose brow crowned also, with a wood (61-62), and who is attended by the masculine cinnamon-scented Zephyr (69). Like Apollo, Silvanus too wears foliage in honour of his lost love, the male Cypressus (121).

In Elegy VII the poet taunts Cupid and then finds himself falling for a woman. Cupid, however, is described by a comparison with the classical figures of Hylas and Ganymede:

Suddenly Love stood by my bed, unwearied Love in painted wings. The swinging quiver betrayed the god where he stood; his 
face, his sweetly threatening eyes, and whatever else becomes a boy, and Love betrayed him. Thus the Sigeian youth appears on eternal Olympus as he mixes brimming cups for amorous Jove; or Hylas, son of Theodamas, who snatched away by a naiad, enticed the beautiful nymphs to his kisses. He had assumed a wrathful countenance, but you would have thought that it became him; and he uttered harsh threats full of bitterness. (17-26)

As we shall see from the banquet temptation of Paradise Regained, homoeroticism may be implicit in the mention of Ganymede and Hylas - but it is ambiguous and subtle. Jupiter is amorous but the subject of his desire is uncertain: is it directed towards his Sigeian cupbearer Ganymede, or one of his many other (mostly female) conquests? Similarly with Hylas, his former relationship to Hercules is not mentioned, and he is described here as actively enticing the nymphs with his kisses. His lover Hercules is, however, mentioned later in the poem, along with his ambiguous friend, in Cupid's list of conquests (140).

These ambiguously sexual references are reinforced, however, by other descriptions of Cupid's attractiveness in the elegy, such as "Whatever else becomes a boy" (20), and "He had assumed a wrathful countenance, but you would have thought it became him” (25). Clearly Milton's comprehension of human sexuality lies beyond the narrow confines of the heterosexual/homosexual binary, exhibiting an understanding of sexuality more along the lines of the Classical attraction to both genders. Hylas and Ganymede are epitomes of male attractiveness; they both share a beauty that is so overpowering that those who see them are compelled to "snatch" them away from their loved ones and transport them to a different world, up to Olympus, or down under the water. Hylas is taken from a homoerotic relationship with Hercules to the heteroerotic world of the nymphs, reflecting a somewhat fluid sexuality. Likewise Jupiter, his attraction to Ganymede aside, is most often associated with the seduction of mortal women.

The primary purpose of Hylas and Ganymede in both these examples is to highlight by comparison the beauty of those they describe; the beauty of each of the young men attendants at the temptation feast and of Cupid appearing before Milton is superior to that of Ganymede and Hylas, epitomes of male beauty. Ganymede was so beautiful that even the king of the gods, known for his seduction of, and affairs with, mortal women, took him up to heaven where he could be constantly at his side. Hylas was so beautiful that both the great Hercules and the nymphs were enamoured with him: the latter abducted him so that he would be with them constantly, which drove the former to abandon his quest with the Argonauts in order to seek him, albeit in vain. Both these mythic tales share the trope that the beauty of the young man is so overpowering that those seeing him are driven to abduct him - in the elegy this reiterates the power of Cupid and is appropriate to his description. 
Interestingly, these same two figures are invoked in Paradise Regained with similar homoerotic connotations. For unlike the other temptations, the second temptation that appears in Book II is not biblically based, but rather an invention of Milton's.

After failing to tempt the Son into turning rocks to bread in Book I of Paradise Regained, Satan returns to the council that was awaiting news of his success. He had first summoned the council after witnessing the Son's baptism (where the Holy Spirit had descended upon him) and they had unanimously agreed to his suggestion that he should be the one who tempted Jesus, as he had previously had success with Eve. He asks for suggestions for what to do next, in a scene reminiscent of the council scene in Book II of Paradise Lost. Unlike that council, however, where several of the fallen spirits made suggestions, here only Belial (who had also spoken in the original council) speaks up. He had originally counselled that they resign themselves to dwelling in hell in "ignoble ease, and peaceful sloth, / not peace" (Paradise Lost, II.226-27); here Belial, described as "the dissolutest spirit that fell" (II.150), suggests that they should try to tempt Jesus with the beauty of women: "Set women in his eye and in his walk..." (II.153). He then describes at length the lure of female beauty (II.153-68), concluding that even the wise Solomon had succumbed to feminine temptation:

Women, when nothing else, beguiled the heart

Of wisest Solomon, and made him build,

And made him bow to the gods of his wives. (II.169-71)

This suggestion is rejected by Satan, however; he mocks Belial's obsession with women, accusing him of being unable to comprehend anyone experiencing anything other than his own desires :

Belial, in much uneven scale thou weigh'st

All others by thyself; because of old

Thou thyself dot'st on womankind, admiring

Their shape, their colour, and attractive grace,

None are, thou think'st, but taken with such toys. (II.173-77)

Satan then mentions the examples of Alexander the Great and Scipio Africanus as men who are immune to feminine wiles:

Remember that Pellean conqueror,

A youth, how all the beauties of the East

He slightly viewed, and slightly overpassed;

How he surnamed of Africa dismissed

In his prime youth the fair Iberian maid (II.196-200).

He disparages Belial's example on the grounds that Solomon was too easily satisfied with his lot in life, and thus was vulnerable to temptation: 
For Solomon he lived at ease, and full

Of honour, wealth, high fare, aimed not beyond

Higher design than to enjoy his state;

Thence to the bait of women lay exposed (II.201-4).

He sees the Son as being more ambitious; like Scipio and Alexander, the Son aims for higher things:

But he whom we attempt is wiser far

Than Solomon, of more exalted mind,

Made and set wholly on the accomplishment

Of greatest things ... (II.205-7)

Satan also mocks those "weak minds" susceptible to the power of beauty, emphasising how easy it is to overcome:

$$
\text { ... for beauty stands (II.220) }
$$

In the admiration only of weak minds

Led captive; cease to admire, and all her plumes

Fall flat and shrink into a trivial toy,

At every slighting quite abashed:

Thus Satan argues that they must instead try tempting the Son with more elevated fare:

Therefore with manlier objects we must try

His constancy, with such as have more show

Of worth, of honour, glory and popular praise;

Rocks whereon greatest men have oftest wrecked (II.225-28)

But he mitigates this by including the possibility of tempting him with basic needs like food:

Or that which only seems to satisfy

Lawful desires of nature, not beyond;

And now I know he hungers where no food

Is to be found, in the wide wilderness (II.229-32)

Realising that the Son will be susceptible to hunger, Satan gathers spirits like him in cunning in order to plan a temptation to lure the Son into eating:

Then forthwith to him takes a chosen band

Of spirits likest to himself in guile

To be at hand, and at his beck appear,

If cause were to unfold some active scene

Of various persons each to know his part; (II.236-40)

The presence of the spirits, who appear as attractive young men and nymphs, is interesting as it brings into question Satan's earlier assertion that the Son was immune to the lure of beautiful women. For both the male and female spirits, who are described as being "fairer" than Hylas and Ganymede, and knight-enrapturing fey damsels respectively, are all exemplars of overwhelming beauty:

At a stately sideboard by the wine

That fragrant smell diffused, in order stood 
Tall stripling youths rich-clad, of fairer hue

Than Ganymede or Hylas, distant more

Under the trees now tripped, now solemn stood

Nymphs of Diana's train, and Naiades

With fruits and flowers from Amalthea's horn,

And ladies of the Hesperides, that seemed

Fairer than feigned of old, or fabled since

Of fairy damsels met in forest wide

By knights of Logres... (II.350-60)

But Satan has promised the council that he will test the Son at every opportunity: "The rest commit to me, I shall let pass / No advantage, and his strength as oft assay" (II.234-35). This accounts for the complex nature of the temptation banquet, where Satan describes the various spirits as those of the natural elements come to pay their respects:

All these are spirits of air, and woods, and springs,

Thy gentle ministers, who come to pay

Thee homage, and acknowledge thee their Lord (II.374-76).

The presence of these spirits along with the lavish food, wine, music and perfume all combine to provide a seductive temptation that assails all the senses. But despite the apparent innocence of the pastoral scene, each of these elements represents a potential pitfall. The wine is a potential intoxicant - especially for someone who has gone without eating for forty days - and music and perfume could lull the senses and lure the Son into a false sense of security. The food itself, despite Satan's repeated claims to the contrary, on closer inspection reveals various meats and fish deemed unclean in Old Testament law:

In ample space under the broadest shade

A table richly spread, in regal mode,

With dishes piled, and meats of noblest sort

And savour, beasts of chase, or fowl of game,

In pastry built, or from the spit, or boiled,

Grisamber-steamed; all fish from sea or shore,

Freshet, or purling brook, of shell or fin,

And exquisitest name, for which was drained

Pontus and Lucrine bay, and Afric coast. (II.339-47)

Despite Satan's repeated assertions that the food offered was not "Meats by the law unclean" (II.328) and "These are not fruits forbidden, no interdict / Defends the touching of these viands pure" (II.370), some of the foods offered are in fact biblically unclean; Satan is lying. Jews were commanded in the Hebrew Bible to eat only "Any animal that has divided hoofs and is cleft-footed and chews the cud" (NRSV Lev., 11:3) and only fish with scales (Lev., 11:9-10), which excludes the "beasts of chase" (II.342) and "all fish...of shell or fin" (II.336-37). Satan lies when he says the food is not unclean, nor offered by an enemy (II.330), so his claim that the food was not "offered first / To idols" (II.328-29) cannot really be trusted. Satan's suggests that even if the food was 
unclean, circumstances would permit its eating for survival (II.330-31). The attendants themselves are also more dangerous than they appear, as evidenced by the sounds that they make when the temptation is refused: "With that / Both table and provision vanished quite / With sound of harpies' words, and talons heard" (II.401-3).

What Satan does not know is that the night before, while he and his followers were planning the temptation, the Son had dreamed of the miraculous feeding of Elijah by both the angel (II.27376) and the ravens:

And saw the ravens with their horny beaks

Food to Elijah bringing even and morn, Though ravenous, taught to abstain from what they brought (II.267-69)

He had also dreamt that he shared food with both Elijah and Daniel: "Sometimes that with Elijah he partook, / Or as a guest with Daniel at his pulse" (II.277-78). The significance of Daniel's "pulse" is that he had defied the King of Babylon's orders to eat unlawful meat and wine and instead stuck to a simple diet of pulses (Dan. 1:8-16). Satan's reference to Daniel (II.329) only serves to reinforce this parallel. Thus when Jesus rejects the "pompous delicacies" (II.390) offered and says he does not like the giver, he is drawing on his recent experiences of the simple intimacy and honour of eating with the prophets - the complexity of the temptation pales in comparison. Unlike in his experience with the prophets, Jesus senses that here he cannot trust Satan, counting his "specious gifts no gifts but guiles" (II.391), which is accurate as he has lied to him about the food, being an enemy, and the true nature of the spirits. Also, in contrast to the communal sharing of food that the Son has experienced in his dreams, Satan does not offer to eat with him - it is an offering of feigned servitude, not friendship.

Two critics in particular, Bredbeck and Summers, have engaged with this temptation by arguing for a sexual element to the banquet, particularly the homoerotic potential present in the description of the male spirits, or as Bredbeck puts it: "Milton gives the Son's temptation a fleshly taunt that Eve's lacks: the appeal of male-male eroticism" (264). I want to focus on their arguments around three key points. The first of these is the problem that any argument for eroticism in the temptation feast faces: accounting for Satan's outright rejection of the suggested sexual temptation, as being something only men of "weak" [II.221] minds fall prey to. Bredbeck argues that the temptation itself is not that of food but rather sexual attraction, introduced by Belial's earlier suggestion to tempt the Son with women. In rejecting Belial's suggestion, Satan is only really rejecting his limited comprehension of sexual temptation as shown by the attractive male attendants (264). Bredbeck points out that in the Old Testament tradition, Belial is associated with transgressions from the ways of God. One might expect that he would be the one to suggest the 
homoerotic temptation, but instead Belial speaks the language of patriarchy; his description of the overwhelming attraction of female beauty mirrors the warnings of Renaissance fathers to their sons about the dangers of female attraction. Thus when Satan responds by describing the Son as immune to such temptations through his ambition, he speaks in the language of ideal Renaissance masculine rhetoric. For Bredbeck, homoeroticism is no longer a vice associated with Belial but an untested alternative outside the patriarchal perspective with which to test the Son, giving a new meaning to Satan's "with manlier objects we must try / His constancy" (II.225-26). This is figured metaphorically by the allusion to Ganymede and Hylas. Indeed Milton's outline of his planned Sodom tragedy avoids the mention of sodomy or the sons of Belial, signifying a difference in interpretation (Bredbeck 271-72).

Summers, however, argues that when Satan overtly rejects Belial's suggestion, he is in fact adopting it in a similar way to the rhetorical technique of apophasis, where one affirms something through the denial of it; for despite his refutation of Belial, Satan does include a thinly-veiled eroticism in the temptation ("Temptation", 50). According to Summers, Satan's reasons for doing this despite his denial reflect his political and competitive nature; his purpose in talking to the council is not to seek advice, but by underlining the difficulty of the task before him he both emphasises its heroic nature and lays the groundwork for an excuse if he fails. Thus Satan solidifies his position as leader, and his denial of Belial's suggestion is motivated by his unwillingness to share the spotlight, just as in the council in Pandemonium at the beginning of Book II of Paradise Lost. Summers points out that Satan's temptation is carefully worked to appear different enough from Belial's suggestion to show no indebtedness to him, even though Belial's traditional associations with homosexuality may have inspired that aspect of the temptation (52). Summers also argues that when Satan highlights how some men are immune to the charms of women this carries the "unstated corollary" that some such men have a primary attraction to their own sex. This explains the inclusion of the attractive youths who are fairer than Ganymede or Hylas (53).

I think these arguments for sexual temptation find support within the textual context of the temptation passage. For upon the Son's final refusal, Satan acknowledges that he is immune to any "allurement":

By hunger, that each other creature tames,

Thou art not to be harmed, therefore not moved;

Thy temperance invincible besides,

For no allurement yields to appetite (II.406-9)

He had used the same term at the council earlier to describe his successful corruption of Adam through his seduction of Eve: "Though Adam by his wife's allurement fell” (II.134). From this repeated use of "allurement" it is clear that Satan was testing not only the physical hunger of the 
Son, but also his sexual "appetite". The description of the temptation feast itself contains a direct reference by Milton to the temptation of Eve: "Alas how simple, to those cates compared, / Was that crude apple that diverted Eve!' (II.350). Of all the temptations this one is indeed the most like the temptation of Eve, not only in that it is centred around eating food, but also in the underlying sensuality; but here, just as the food is more varied and complex, so is the seduction.

The second point is that of the significance of the allusion to Hylas and Ganymede. Both Bredbeck and Summers comment that by the time of the Renaissance, Ganymede was no longer just a mythological figure but also a generic term for a male concubine (264; 53-54). Bredbeck also points out that Milton himself uses Ganymede as a homoerotic equivalent of mistress in his plans for a tragedy about the fall of Sodom, which shows his awareness of the vernacular use of the term Ganymede (264). According to Summers, Hylas was seen as symbolising the power of a youth to conquer an older male; he and Hercules make an appearance in several Renaissance texts, often alongside Jupiter and Ganymede. Summers also comments briefly that both couples appear in Milton's account of his own sexual awakening in his seventh elegy (54).

Bredbeck argues that since these mythical young men captured the attention of the god Hercules and the hero Hercules respectively, the allusion here through the attractive youths casts the temptation of the Son into the same heroic mould. For Hercules and Hercules share, as well as an attraction to beautiful youths, what Satan offers to the Son: "dominion, wealth and fame" (Bredbeck 263). The metaphors of Ganymede and Hylas, through their vernacular usage, reflect the power difference between the god or hero and the lesser object of their affection; these pederastic relationships represent the power and dominance of the epic figure (264). For Summers, Satan's determination to try the Son with "manlier objects" could be an underlying reference to the Renaissance homosexual term of "masculine love", which had been used to describe the relationship of Jupiter and Ganymede (54). While Bredbeck focuses on the epic allusions, Summers examines the earlier mention of the historical figures of Alexander the Great and Scipio Africanus.

He points out that as well as being reputedly of divine origin, Alexander and Scipio were both public figures and, like Jesus, known for their charity and temperance (54). They were also known, however, for their close, homoerotic male friendships, and appreciation for male beauty (54-55). Thus, Summers argues, when Satan rejects Belial's heteroerotic suggestion by invoking these two men, he also foreshadows the inclusion of a homosexual lure in the temptation alongside the heterosexual one (55). Alexander was renowned for slighting female beauty; despite marrying for dynastic purposes, his primary relationships were with men, particularly his close companion Hephaestion - this relationship was at times seen as an "example of elevated homosexual love" (Summers 55). Summers points out that like Jesus, Alexander emphasised self-control over the 
control of others, but he cites two episodes in Alexander's life where the Macedonian abandoned this self-restraint, to which Satan may be intimating (ibid). The first and more famous episode is that of Alexander's intense reaction to the death of Hephaestion to the point of taking his anger out by the indiscriminate killing of civilians, showing how even the most moderate of men can be led to irrational behaviour by love (55-56). The second episode, interestingly, also takes place in a similar context to the temptation. When invading India, Alexander and his army had travelled for about sixty days through rough terrain, so after arriving in Carmania, Alexander abandoned his usual restraint and joined his men in a raucous week of relaxation. During this time of feasting and drinking, the usually temperate Alexander became enamoured with a young male dancer, Bagoas. From this, according to Summers, it seems likely that Satan was hoping that the Son might fall for one of the male attendants given the similar context (57).

As for Scipio Africanus, Summers points out that the Roman welcomed comparisons with Alexander and was similarly known for both moderation and close male friendships, his greatest friendship, with Laelius, being immortalised in Cicero's De Amicitia. Like Alexander, Scipio was known for temperance and honour: even after capturing the wealthy city of Carthage he took nothing from it, despite his own humble circumstances. Satan's reference to the dismissal by Scipio of the "fair Iberian maid" refers to Scipio's restoration of a beautiful young woman to her fiancé, as described by Livy (Summers 58). But unstated by Satan is the event that occurs at a following conquest, where Scipio, after taking some 12,000 prisoners captive, decided to free an attractive youth named Massiva, and also gave him many expensive gifts. Summers argues that it follows from this that Satan was aware that Scipio was not just immune to the charms of the Iberian maid, but also susceptible to the attraction of male beauty, as shown by his favours to Massiva (58). Bredbeck's and Summers' arguments here are complementary, for the features of both Alexander and Scipio that Summers highlights provide historical equivalents to the qualities of the epic hero that Bredbeck advocates. It seems Alexander, Scipio, Jupiter and Hercules all share the epic desire for both glory and attractive young men.

In Paradise Regained the invocation of both these figures through their irresistibility adds weight to the idea that the young servers are present as part of a sexual temptation. The description of the "Tall stripling youths" (II.352) as being "by the wine" (II.350) coupled with the reference to "Ganymede" (II.353) implies that the young men are there as potential cupbearers just as Ganymede served as a cupbearer to Jupiter. Interestingly Hylas too is associated with providing liquid refreshment as he was fetching water for Hercules when he was abducted by the nymphs (Theocritus, XII). These allusions to the overpowering beauty of these young men carry the implication that like Ganymede, Hylas, Bagoas, and Massiva, one of them may compel favour from 
a powerful older man, in this case the Son, just as Jupiter, Hercules, Alexander and Scipio had bestowed theirs. Satan points out his age later in Book III: "Thy years are ripe, and over-ripe" (31), comparing him in age to Alexander (31-34), Scipio (34-35) and Pompey (35-36) at the peak of their power. Alexander is also referred to again in the Philosophy temptation of Book VI where Satan lists among "The schools of ancient sages" (251) that of Aristotle, "his who bred / Great Alexander to subdue the world" (IV.251-52). Milton's knowledge of Alexander is clearly comprehensive, which lends some weight to the argument of Summers.

Bredbeck and Summers do differ slightly in their interpretations of the roles of the female temptresses in this temptation. Bredbeck sees them as posing a complementary temptation to that of the young men $(268,271)$, whereas Summers suggests that they are there in the background to help obscure the homoeroticism of the male temptation (58-59). While Summers' suggestion is overtly more consistent with Satan's refutation of Belial, I think the case for Bredbeck's is stronger because of a parallel construction to the masculine temptation within the text itself, as well as similar treatments in other of Milton's works. For while the women do appear in the background of the scene, their bewitching attractiveness to men is similarly emphasised through an allusion to the "fairy damsels" and knights of Chivalric romance:

Fairer than feigned of old, or fabled since

Of fairy damsels met in forest wide

By knights of Logres, or of Lyonesse,

Lancelot or Pelleas, Pellenore (II.358-61).

Just as the young men are described as being "fairer" than both Ganymede and Hylas, so too are the women described as being "fairer" than those to whom they are being compared; this repetition implies a degree of equivalence. In addition, for Satan to acknowledge the Son to be immune to any "allurement" (II.409), keeping in mind Satan's promise to the council to "let pass / No advantage" (233-34), one would expect that Satan would also test the Son's attraction to women, even if he did doubt the effectiveness, as he has nothing to lose by doing so and everything to gain. Finally, as Bredbeck has pointed out, Milton had equated (homosexual) catamites with (heterosexual) mistresses in his planned tragedy “Cupid's Funeral Pyre: Sodom Burning” (Bredeck 264). We have seen a similar conjunction of paralleled homosexual/heterosexual attraction in Milton's seventh elegy. So it seems more likely that the sexual temptation by the women is on an equal footing to that of the men; Satan is hedging his bets in regards to the Son's sexual attraction.

The third point is to examine what Bredbeck and Summers think motivates Milton to include this homoerotic element. Bredbeck argues that Milton is rebelling against the narrow patriarchal gender conceptions by portraying the Son as representing the perfect man who is "subject neither to the weakness of female flesh nor to the prurience of deviant male flesh" 
(Bredbeck 271). Summers suggests that Milton creates this temptation as a defence against the heretical notion that Jesus and John the beloved disciple had a homosexual relationship (60-61). Both, however, agree that Milton's conception of human sexuality is more fluid that what is conventionally expected. For Bredbeck, Milton's awareness of the deviant elements within his historical context is displayed in Paradise Lost, in such examples as the gendered nature of the masculine sun and feminine moon that both "animate" (VIII.151) the earth, and the sameness and immortal nature of the angels, united with God, which defy the "fleshly dichotomies" of traditional commentary (Bredbeck 274). For Summers, Paradise Regained also lacks the condemnation of homosexuality that might be expected (61-62).

I think that, given the similar obliquity used by Milton in his seventh elegy in his allusions to Ganymede and Hylas as well as the support for a sexual temptation inherent within the text of Paradise Regained itself, Bredbeck and Summers have a strong case when arguing for homoeroticism in the banquet temptation. Satan's use of the term "allurement" both before the temptation to describe Eve's corruption and seduction of Adam and afterwards to describe the Son's resistance to any temptation, clearly, I think, shows that Milton's Satan was intending to tempt the Son on a full spectrum of attraction, playing on the connections between food and sexual desire, "appetite" (II.409). The fact that Satan, whom the Son accuses of being "composed of lies / From the beginning" (I.407), lies outright about the unlawful nature of the food in the same passage strengthens the case for him being duplicitous in his dismissal of Belial's suggestion to use women as the temptation. So it is clear that the Son is not only being tempted by hunger for food, but also sexual desire.

The fact that the young men are present as homoerotic objects of temptation is reinforced by the allusion to both Ganymede and Hylas, particularly with the Renaissance use of Ganymede as a term to represent a catamite as used by Milton himself. In addition, their appearance next to the wine solidifies their role as potential cupbearers, alluding to Ganymede's role as a cupbearer to Jupiter and in doing so aligning the Son with the epic hero epitomised both by the prime deity of Classical tradition and, through Hylas, its foremost hero, as Bredbeck has argued. More tenuous is Summers' argument for a conscious use of Scipio and Alexander by Milton for their homosexual connections, as there is little direct evidence in the text. Both arguments are complementary, however, in that they are focused on the idea of the Son being cast into a heroic mould; if we do accept that the young men who are more attractive than Hylas and Ganymede, the paragons of youthful male beauty, are there to serve as a homoerotic temptation for the Son by implicitly aligning him with the heroic paragons of Classical tradition, then this identification is strengthened by the reference to the legendary historical figures of Alexander and Scipio with their respective 
attractions to Bagoas and Massiva, as well as their famous male relationships. Taken together both accounts allow an interpretation that is more comprehensive than either of them alone, as Summers even acknowledges in his first footnote (65).

All things considered, Milton's use of Hylas and Ganymede in this freshly conceived temptation clearly carries homoerotic undertones, in the light of similar works and the text itself. A broader implication of this is that Milton's approach to human sexuality is clearly more complex than might be expected, implying a benevolent understanding of same-sex attraction on an equal weighting with that of the opposite sex. With this in mind we will now turn to a closer examination of the desire and intimacy portrayed in Paradise Lost so as to reach a full understanding of angelic sexuality. 


\section{ChaPter Five: Desire AND LOVE}

\section{The Attractions of Beauty, Manly Grace and Wisdom}

We now proceed to establishing the context of how attraction and desire function within the epic before examining the few examples of sexual intimacy that appear. In Paradise Lost there are three primary attributes that evoke attraction and desire from the beholder: beauty, grace, and wisdom (or virtue). Of these three attributes, the use of beanty is probably the closest to our modern understanding. According to the OED, the beauty can be defined as:

Such combined perfection of form and charm of colouring as affords keen pleasure to the sense of sight: a. in the human face or figure (1.a.).

We may note the exclusively passive and visual nature of this quality. Milton also uses fair, rather than beautiful, as the adjectival form to describe this outer beauty. In contrast grace is used by Milton to describe the attractive nature of the subject's behaviour or speech. The appropriate definition from the OED for grace is:

Pleasing quality, gracefulness; The quality of producing favourable impressions; attractiveness, charm. Now usually with more restricted application: The attractiveness or charm belonging to elegance of proportions, or (especially) ease and refinement of movement, action, or expression (OED I. 1. a.).

Unlike beanty, grace is not limited to what is seen, but rather describes active beauty, 'poetry in motion' as it were. Milton often uses it to highlight attractiveness in movement, and other actions but also uses it to describe speech, an aural quality. The third attractive quality that appears in Paradise Lost is that of inner goodness, often described as wisdom:

The quality or character of being wise, or something in which this is exhibited. Capacity of judging rightly in matters relating to life and conduct; soundness of judgement in the choice of means and ends; sometimes, less strictly, sound sense, esp. in practical affairs: opp. to folly (OED 1. a.).

Similar terms such as virtue and good are also used by Milton to describe inner attractiveness; all these terms involve doing what is right; Adam uses a series of similar superlatives, "wisest, vituousest, discreetest, best" (VIII.550), to describe the apparent superiority of Eve's "inward faculties" (VIII.542).

In summary, then, when speaking in terms of attractiveness, beanty refers to the outer appearance; grace describes actions such as speech, movement and behaviour; and wisdom the inner 
good judgement and understanding. These attributes are not exclusive and often appear in combination.

These three terms are used by both Adam and Eve in describing their attractions to one another. Despite being initially overwhelmed by her own reflected beauty, Eve later comes to the realisation that "beauty is excelld by manly grace / And wisdom which alone is truly fair" (IV.490491). This observation ranks the three qualities by placing them in an ascending order from beauty to grace to wisdom, the latter being what is authentic in its beauty. These lines occur at the end of Eve's account of her creation: upon awakening she is entranced by her own reflection in a scene that parallels the myth of Narcissus (IV.461-69). After meeting Adam, despite acknowledging his attractive appearance (IV.477), Eve desires instead to return to the superior beauty of her own reflection (IV.478-80). But she is stopped from doing so by Adam, and then realises that there are other things more attractive than outer beauty, namely the "manly grace" and "wisdom" of Adam that makes him superior in her eyes. It is worth noting though, despite her the overwhelming nature of her self-attraction, Eve does find herself feeling a degree of attraction to Adam's appearance: "fair indeed and tall" (IV.477), even before she realises that his "manly grace" and wisdom are superior to her own reflected beauty. As well as the obvious physical reference OED defines "manly" as:

Of a person: having those qualities or characteristics traditionally associated with men as distinguished from women or children; courageous, strong, independent in spirit, frank, upright, etc. (2. a.).

Thus "manly grace" can be seen to mean the attractiveness of Adam's masculine behavioural qualities, but also as reinforcing the trope of masculine active dominance being superior to feminine passivity.

Adam also makes use of these three qualities but for him the beauty and grace of Eve overwhelms his own wisdom and makes her seem wise. Where Eve finds that Adam's wisdom is ultimately the most attractive quality, for Adam, Eve seems even wiser than the personification of Wisdom herself. For in describing to Raphael his account of Eve's creation story, Adam describes her as being more beautiful than anything else he had ever seen:

Under his forming hands a Creature grew, Manlike, but different Sex, so lovly faire, That what seemd fair in all the World, seemd now Mean, or in her summd up, in her containd And in her looks, which from that time infus'd Sweetness into my heart, unfelt before, And into all things from her Aire inspir'd The spirit of love and amorous delight. (VIII.470-77) 
Not only is Eve ascetically attractive, but this beauty inspires the "spirit of love and amorous delight" (VIII.477) in others; Adam finds himself newly overcome with erotic desire upon seeing her:

Transported touch ${ }^{13}$; here passion first I felt, Commotion strange, in all enjoyments else Superiour and unmov'd, here onely weake Against the charm of Beauties powerful glance. (VIII.530-3)

Not only does Eve look beautiful but her actions also display grace: "Grace was in all her steps, Heav'n in her Eye, / In every gesture dignitie and love" (VIII.488-89).

In the eyes of Adam the perfection of Eve's outer beauty and graceful actions is such that she seems to possess an equivalent perfection of inner beauty:

Her loveliness, so absolute she seems

And in her self compleat, so well to know

Her own, that what she wills to do or say,

Seems wisest, virtuousest, discreetest, best; (VIII.547-50).

"All higher knowledge" pales in comparison (VIII.551), and even Wisdom herself is overwhelmed by the beauty and grace of Eve: "Wisdom in discourse with her / Loses discount'nanc't, and like folly shewes" (VIII.551-53). Rather than being exalted as being "truly fair", in the eyes of Adam Wisdom herself appears unable to compete with the perfection of Eve. The contrasting realisation of Eve, however, reflects Raphaels response to Adam where the angel likewise values inner wisdom over outer beauty, berating the first man for this oversight:

\section{... be not diffident}

Of wisdom, she deserts thee not, if thou

Dismiss not her, when most thou need'st her nigh,

By attributing overmuch to things

Less excellent, as thou thyself perceiv'st.

For what admir'st thou, what transports thee so,

An outside? fair no doubt, and worthy well

Thy cherishing, thy honouring, and thy love,

Not thy subjection (VIII.562-70).

Raphael had earlier in their dialogue encouraged Adam to "be lowly wise" (VIII.173) by focusing on the challenges of his day to day life rather than being distracted by esoteric musings (VIII.17078). Adam agreed declaring that this is the "prime wisdom" (VIII.194) lest he should be "in things

13 I. Literal and directly connected senses. Here probably: 1 . b. euphem. Sexual contact.

Interestingly, see also: 1667 Milton Paradise Lost vi. 520 Part incentive reed Provide, pernicious with one touch to fire. - cited by the OED as 2. a.

The act, fact, or state of touching or being touched (of inanimate objects, or as an involuntary act: see touch v. 3 ); contact. 
that most concern / Unpractised, unprepared, and still to seek (VIII.196-97). Here again Raphael is imploring Adam to use his inherent wisdom to do what is right rather than being distracted by the attraction of a mere "outside" (VIII.568). In doing so Raphael warns Adam to avoid letting this attraction to Eve's beauty and the "delight" (VIII.580) of the sexual act, "the sense of touch whereby mankind / Is propagated" (VIII.579-80), draw him into "carnal pleasure" (VIII.593) and instead focus on the elements of true love that have the potential to evolve into heavenly love:

What higher in her societie thou findst

Attractive, human, rational, love still;

In loving thou dost well, in passion not, Wherein true Love consists not; love refines

The thoughts, and heart enlarges, hath his seat

In Reason, and is judicious, is the scale

By which to heav'nly Love thou maist ascend,

Not sunk in carnal pleasure, for which cause

Among the Beasts no Mate for thee was found. (VIII.586-94).

Here Raphael introduces a hierarchy of love that parallels Eve's hierarchy of attractiveness: passion, true love and heavenly love. Raphael's suggestion to Adam implies that paying heed to Wisdom can lead to an ascension to an experience of heavenly love expands upon the angel's earlier remarks on how they might later be allowed to eat with angels (V.493-95) with the eventual result that their physical bodies would evolve into spiritual (V.496-98) so that they may "winged ascend / Ethereal" (V.498-99). This fits into the logic of Paradise Lost in that the ultimate purpose for the creation of humans was to fill the space in heaven left by the fallen angels.

Adam however responds "half abashed" (VIII.595), informing Raphael that what he appreciates most about Eve is not her physical beauty (VIII.596), nor the sexual intimacy that he enjoys with her (VIII.597-99), but rather her "graceful acts" (VIII.600) that reflect the harmony of their relationship: "Union of mind, or in us both one soul" (VIII.604). Adam is asserting that it is not her physical beauty that he is most attracted to but rather her graceful behaviour, mirroring Eve's earlier assertion that his "manly grace" was more attractive than mere physical beauty. We can see here an aligning of outer beauty with physical desire, graceful behaviour with true love, and wisdom with ascension to heavenly love.

The question arises as to whether Adam's attraction to Eve reflects "carnal pleasure" or "true love"? The passage immediately following Eve's origin story displays the erotic attraction between the two:

So spake our general mother, and with eyes

Of conjugal attraction unreproved,

And meek surrender, half embracing leaned

On our first father, half her swelling breast

Naked met his under the flowing gold 
Of her loose tresses hid: he in delight

Both of her beauty and submissive charms

Smiled with superior love, as Jupiter

On Juno smiles, when he impregns the clouds

That shed May flowers; and pressed her matron lip

With kisses pure (IV.492-502).

It seems clear that the attraction between the two aligns more with true love than carnal passion as shown by Adam's “kisses pure” (IV.502) and Eve's “conjugal attraction unreproved/ And meek surrender" (IV.492-93). Also, despite their mutual erotic attraction, the two remain restrained from full sexual intimacy outside the privacy of their bower as shown by the repeated emphasis on the partial nature of their physical touching as shown in how Eve " half embracing leaned / On our first father, balf her swelling breast / Naked met his" (IV.494-96, italics mine). This intimacy is nonetheless hidden by the "flowing gold / Of [Eve's] loose tresses" (IV.496-97) bestowing the pair with natural modesty. Adam's response conveys love rather than passion but still carries undertones of eroticism:

$$
\ldots \text { he in delight }
$$

Both of her beauty and submissive charms

Smiled with superior ${ }^{14}$ love, as Jupiter

On Juno smiles, when he impregns the clouds

That shed May flowers; and pressed her matron lip

With kisses pure. (IV.497-502)

The "superior" nature of Adam's love is ambiguous as it could refer to the first man's higher authority over Eve, or it could refer to the higher nature of the love, or both. This passage emphasises the feminine tropes of Eve's marital role in its allusions to marriage, and motherhood in her description: "general mother" (IV.492), "conjugal attraction" (IV.493), and "matron lip" (IV.501).

In doing so it also emphasises her feminine submissiveness to Adam: "meek surrender" (IV.494) and "submissive charms" (IV.498), so reading "superior" as referring to Adam's dominance over Eve seems to fit the context well. However, considering Adam's "kisses pure" (IV.502), the use of superior could also refer to the higher nature of his love given that his restrained response to Eve's physical "beauty" (IV.498) and the grace of her "submissive charms" (Ibid) is clearly more in line with Raphael's definition of rational true love than the recklessness of animalistic passion. The metaphor of Jupiter and Juno both parallels the masculine superiority of

\footnotetext{
14 OED: II. "Senses referring to status or rank." 6. a. "Higher in rank, status, position, or office; having more authority; higher-ranking, senior"; 7. a. "Higher in notional or abstract rank, or in a scale of a series; of a higher or better nature or character..."
} 
Adam over his wife but also highlights the wisdom involved in the ruling over others, a responsibility both Adam and Jupiter share. Aligning Adam with both the wisdom and divinity of Jove highlights the association between wisdom and the ascension to a higher state.

But, as Raphael tries to warn Adam, an attractive appearance may not truly reflect reality; three aspects of beauty and their associated desires can be exploited as shown in both Satan's temptation of Eve and her resulting temptation of Adam. Satan, "enclosed / In serpent, inmate bad" (IX.494-95), appears physically attractive, "pleasing was his shape, / And lovely never since of serpent kind / Lovelier" (IX.503-5). But he also describes the tree and its fruit to Eve in terms of physical beauty: "A goodly tree far distant to behold / Loaden with fruit of fairest colours mixed, / Ruddy and gold" (IX.576-78). Just as Eve herself is an object of beauty that actively seems to allure her viewers, the fruit exudes a delicious scent attracts those who see and smell it. Satan falsely describes both the serpent and the other animals as being overcome with "desire" (IX.584; 592) for the fruit but nonetheless Eve finds herself overcome with a like "desire" in the presence of the tree and its fruit:

Meanwhile the hour of noon drew on, and waked

An eager appetite, raised by the smell

So savoury of that fruit, which with desire,

Inclinable now grown to touch or taste,

Solicited her longing eye (IX.739-43).

The physicality of this desire reflects the erotic undertones of the temptation augmented by the seductive grace of the serpentine Satan who in attempting to gain the attention of Eve "Curl[s] many a wanton wreath" (XI.517).

The serpent, possessed by Satan, exploits Eve's sense of her own inferiority by describing to her the tree as a "sacred, wise, and wisdom-giving plant, / Mother of science" (IX.679-80) that brings enlightenment:

... now I feel thy power

Within me clear, not only to discern

Things in their causes, but to trace the ways

Of highest agents, deemed however wise (IX.680-83).

As the serpent, Satan argues that just as eating the fruit has given him wisdom and elevated him to human speech, if Eve were to eat of it also she would similarly gain wisdom and ascend higher: "Proportional ascent, which cannot be / But to be gods, or angels demigods" (IX.936-37). This argument successfully plays upon Eve's sense of inferiority to Adam (IV.445-48), and is a valid one considering that Raphael had earlier raised the possibility of Adam and Eve ascending to an angelic form as a result of sharing the angels' heavenly food (V.493-99). Though here of course this is a 
lie: the serpent is speaking through Satan's possession of him and not because he ate the fruit himself.

Adam similarly succumbs by the attraction of the fruit when its attractiveness is augmented by Eve's own "charm":

She gave him of that fair enticing fruit

With liberal hand: he scrupled not to eat

Against his better knowledge, not deceived,

But fondly overcome with female charm (IX.996-99).

Defying Raphael's earlier advice, Adam abandons wisdom "Against his better knowledge" (IX.998), choosing instead to succumb to his desire for the "fair enticing fruit" (IX.996), the grace of Eve's "female charm" (IX.999), and the false wisdom that the fruit's "virtue" (IX.973) will bring about ascension: "dilated spirits, ampler heart, / And growing up to godhood" (IX.876-77).

This attractive yet false wisdom that rebellion will lead to the ascension to a greater state of being appears several times in Paradise Lost and plays a role in the fall of both humans and angels. For Eve and Adam both accept the serpent's lie and in eating the fruit they feel that it is affecting them as they expect:

As with new wine intoxicated both

They swim in mirth, and fancy that they feel

Divinity within them breeding wings

Wherewith to scorn the earth (IX.1008-11).

In doing so they echo the earlier example of the rebel angels who experience similar delusions of grandeur, styling themselves as gods:

A third part of the gods, in synod met

Their deities to assert, who while they feel

Vigour divine within them, can allow

Omnipotence to none (VI.156-59).

In both examples the parties delude themselves into thinking that they are able by their own effort to become greater than they are, rather than accepting the "prime wisdom" of being content with their current lot. It is clear that the qualities of beauty, grace and wisdom evoke powerful desires which can be exploited by others.

As the attractions and desires of both Adam and Eve are described in terms of their varying responses to beauty, grace, and wisdom, this provides a framework for a similar analysis of the angelic spirits. The eroticism of physical beauty and its potential for arousing carnal desire in the viewer is highlighted in a direct reference to its effect (or lack of it) on the angels in a narratorial description of Eve's natural beauty, "at table Eve / Ministered naked, and their flowing cups / With pleasant liquors crowned" (V.443-45). The reaction to this sight is both particularly and general, as 
while the only angel immediately present is Raphael, the angel guards watching from a distance are also referenced:

$$
\text { if ever, then, }
$$

Then had the Sons of God excuse to have bin Enamour'd at that sight, but in those hearts Love unlibidinous reign'd, nor jealousie Was understood, the injur'd Lovers Hell. (V.446-50)

The phrase "sons of God" is a biblical allusion to those described by that same epithet in the Book of Genesis who upon seeing the beauty of mortal women took them as brides (6.1-3), the resulting offspring being great heroes (6.4). Milton had alluded to the offspring of such pairings earlier in Book III: "middle spirits hold / betwixt the angelic and human kind: / Hither of ill-joined sons and daughters born" (461-62). But later, in the angel Michael's revelation to Adam, he uses this same phrase to refer to those who are first ambiguously described as "by their guise / Just men they seemed" (XI.576-77) and who are later seduced by what Michael describes as a "fair femal Troop ... that seemed / Of Goddesses, so blithe, so smooth, so gay, / Yet empty of all good wherein consists / Womans domestic honour and chief praise" (XI.614-17).

With all this is mind, we can see how Milton's assertion that only here would "Enamour'd" angels be excused, highlights the degree of Eve's outer attractiveness as well as her grace and virtue, for unlike the other women she possesses the goodness expressed through "domestic honour" (XI.617) displayed in her feeding of Adam and the angel (V.443-45). It also emphasises the temperance of the angels in not being aroused by Eve's attractiveness which aligns Raphael and the other angels with the perspective of "true love" rather than carnal passions of lust and jealousy. For the adjective "Enamoured" is defined by the OED as meaning "Full of the passion of love; in love. Also, in weaker sense, charmed, fascinated". As the angels still feel "Love unlibidinous", it is clear that it is not love they lack, but the passion that can be associated with it; the Miltonic neologism of "unlibidinous" describes the absence of libidinous: "Of persons, their lives, actions, desires: Given to, full of, or characterized by lust or lewdness; lustful, lecherous, lewd” (OED 1). So the angels lack the lustful passion that is analogous with the "carnal pleasure" that Raphael warns Adam against, instead showing the reasoned appreciation that is "true love".

The reaction of those present, again both particular and general, to Eve's later departure may at first glance seem contradictory to the angels' earlier temperance:

With goddess-like demeanour forth she went;

Not unattended, for on her as queen

A pomp of winning graces waited still,

And from about her shot darts of desire

Into all eyes to wish her still in sight (VIII.59-63). 
The cupid-like "pomp of winning graces" shooting "darts of desire", are metaphors that embody the graces of Eve The are however from and carrying that quality's association with true love rather than carnal passion. However both love and passion do share an erotic element, though they differ in their use of it. Thus the erotic implications of "darts of desire" is not incompatible with the true love of the angels watching on, but rather shows their appreciation of Eve free from jealousy and lust.

For attraction to gracefulness (or even physical beauty) does not necessitate a lustful element to that attraction, however overwhelming and erotic that attraction may be. This is shown when Satan experiences a brief but uncharacteristically unlibidinous response to Eve's innocence. Despite her erotic appearance which "sums all delight” (IX.454), Eve’s "heavenly form” (IX.457) and "graceful innocence" (IX.459) momentarily rob him of his evil intent and fallen lust:

$$
\text { ... her every air }
$$

Of gesture or least action overawd

His malice, and with rapine sweet bereav'd

His fierceness of the fierce intent it brought:

That space the evil one abstracted stood

From his own evil, and for the time remained

Stupidly good, of enmity disarm'd,

Of guile, of hate, of envy, of revenge (IX.459-66).

Faced with the innocence of Eve's beauty and grace Satan temporarily regains the innocence that he has lost.

Satan had a similar experience earlier during the encounter with Ithuriel and Zephon when the two lesser angels do not recognise their former prince. This is because, as Zephon informs him, Satan's base form has decayed as a result of his fall into hell (IV.834-40). In doing so the angel provides a visible reminder to Satan of what he has lost:

So spake the cherub, and his grave rebuke

Severe in youthful beauty, added grace

Invincible: abashed the devil stood,

And felt how awful goodness is, and saw

Virtue in her shape how lovely, saw and pined

His loss (IV.844-49).

We see all three of the qualities associated with attraction present in Satan's reaction to his discovery which leaves him standing "abashed” (IV.846), feeling "how awful goodness is" (IV.847). Zephon possesses both "youthful" beauty and "Invincible" grace, but Satan also sees in him an element of inner beauty, "Virtue in her shape how lovely" (IV.847) - not unlike Eve's feminine personification of Wisdom. While the second episode is also tainted by lust as Satan pines more for the loss of his outer beauty than his inner virtue (IV.849-50), both examples still show a glimpse of Satan's former 
virtue and thus how the faithful angels can appreciate the attractiveness of Eve yet avoid lust in this attraction.

The reciprocal attraction between Raphael and Adam, similarly adheres to this "unlibidinous" notion of desire; Book VIII of Paradise Lost opens with the first man left dazed by the grace of the angel's "charming" voice (VIII.1-3), and he later vocalises this attraction:

For while I sit with thee, I seem in heaven,

And sweeter thy discourse is to my ear

Than fruits of palm-tree pleasantest to thirst

And hunger both, from labour, at the hour

Of sweet repast; they satiate, and soon fill,

Though pleasant, but thy words with grace divine

Imbued, bring to their sweetness no satiety. (VIII.210-16)

Raphael responds by complementing Adam on his own speech: "Nor are thy lips ungraceful, sire of men, / Nor tongue ineloquent" (VIII.218-19), and extends this appreciation to the entirety of his appearance and behaviour: "Speaking or mute all comeliness and grace / Attends thee, and each word, each motion forms" (VIII.222-23); He describes these "Inward and outward" (VIII.221) qualities as a being "gifts" (VIII.220) from God reflecting "his image fair" (VIII.221). Thus we see another example of unlibidinous love exhibited in the three qualities of beauty.

While Raphael and the other faithful, watching angels possess neither lust, nor jealousy, the same cannot be said of Satan, who upon seeing the erotic intimacy of Adam and Eve is both aroused and envious:

aside the Devil turnd

For envie, yet with jealous leer maligne

Ey'd them askance, and to himself thus plaind.

Sight hateful, sight tormenting! thus these two

Imparadis't in one anothers arms

The happier Eden, shall enjoy thir fill

Of bliss on bliss, while I to Hell am thrust,

Where neither joy nor love, but fierce desire,

Among our other torments not the least,

Still unfulfill'd with pain of longing pines (IV.502-11)

Here Satan's desire is not shown to be limited to merely Eve, but instead to the couple, an attraction that carries undertones of male bi-eroticism. At first sight, Satan is attracted to the human pair: "whom my thoughts pursue / With wonder, and could love, so lively shines / In them Divine resemblance, and such grace / The hand that formd them on thir shape hath poured" (IV.362-65).

Similarly in his encounter with Zephon, Satan pines for the loss of this inner Virtue but more so the loss of his outer angelic beauty: "chiefly to find here observed / His lustre visibly impaired" (IV.849-50). This emphasis on the loss of his physical beauty, over that of his inner virtue/"goodness" in itself reinforces the extent of his decay (Satan remarks on his decayed form 
later in book IX). Given Satan's narcissistic penchant for reflections of himself this also strengthens the scene's erotic undertones. As Zephon is young, male and beautiful, and Satan is an older male, they both fit into the Classical model of pederastic attraction; the additional presence of a female figure in Virtue (IV.848) lends a bi-erotic undercurrent to the scene not unlike that of the "fair" male and female figures present at the temptation feast in Paradise Regained (II.351-61).

Satan also displays a similar attraction towards Eve one he returns to his usual hate, jealousy and lustful desire (IX.467-79), describing her as "divinely fair, fit love for gods, / Not terrible, though terror be in love / And beauty" (IX.489-91): highlighting both her erotic beauty "fit love for gods" and its erotic power, or "terror", over others. The plurality of the masculine gods also hints at bi-eroticism.

Satan describes a similar longing for his "dalliance” with Sin: "joys / Then sweet, now sad to mention" (II.819-20).

Dear daughter, since thou claim'st me for thy sire,

And my fair son here show'st me, the dear pledge

Of dalliance had with thee in heaven, and joys

Then sweet, now sad to mention (II.817-20)

For despite the ominous warning signs, Satan lets himself fall prey to the seductive wiles of Sin, his own daughter, an act both narcissistic and incestuous, literally "Self-tempted, self-depraved" (III.130). For despite his misgivings Satan became "enamoured" by (II.765) by Sin's "shape and countenance bright" (II.756) that reflected his own "perfect image" (II.764), an ultimately erotic attraction in that in leads to the conception of Death (II.765-67). Here the use of "fair" in describing Death both reflects the degree to which Satan's self-deception has taken him, but also adds another instance of bi-eroticism.

Having examined the three attributes that evoke attraction, and the degrees of desire that they can evoke, we now turn to examining the instances where these desire are actualised in Paradise Lost.

\section{Actualised Desire}

Probably the strongest evidence supporting a physical aspect to the angels' sexuality appears when Raphael tells Adam: "Whatever pure thou in the body enjoy'st / (And pure thou wert created) we enjoy / In eminence" (VIII.621-23). But what exactly is Raphael referring to? Earlier in book IV the Miltonic narrator had provided a commentary on the pure nature of Adam and Eve's prelapsarian sexual intimacy; a comparison with their lapsarian sexual experience in Book IX should assist in clarifying what is meant by this statement. 
In his response to Raphael warning against "carnal pleasure” (VIII.593), Adam asserts in passing that the human sexual act is superior to that of the other animals:

In procreation common to all kinds

(Though higher of the genial bed by far,

And with mysterious reverence I deem) (VIII.597-99).

In doing so his use of "mysterious", in conjunction with the religious tone of "reverence", alludes to the previous night when he had experienced "the Rites / Mysterious of connubial Love" (IV.742-43) with Eve - the narrator also describing their "wedded Love" as a "mysterious Law" (IV.753). The latter phrase is cited by the OED, under "mysterious", as an example of "Of or belonging to religious mysteries; relating to that which is divine and hence beyond human understanding" (A.3.).

Their marriage is also described as the "true source" for human procreation (IV.753), and also as a solution for unbridled sexual desire, "adulterous lust" (749), instead being "Founded in Reason, Loyal, Just, and Pure” (IV.755); it also serves as a prototype for other familial relationships (IV.756-57). Within the 'reasoned' foundation of this married love, the sexual intimacy is not mere "adulterous lust" but rather "loyal, just, and pure, / Relations dear," (IV.755-56).

Just as the Miltonic narrator will take issue with the gloss of theologians that try and explain away the eating of the angels in the following book (V.434-39), here he takes aim at the "Hypocrites" who argue for celibacy rather than married sexuality:

Whatever Hypocrites austerely talk

Of puritie and place and innocence,

Defaming as impure what God declares

Pure, and commands to som, leaves free to all.

Our Maker bids increase, who bids abstain

But our destroyer, foe to God and Man? (IV.744-49)

Milton thus implies that the sexual relations within this marriage are pure and soon states that the joy provided by this "Perpetual Fountain of Domestic sweets" (IV.760) is blameless:

Farr be it, that I should write thee sin or blame,

Or think thee unbefitting holiest place,

Perpetual Fountain of Domestic sweets,

Whose bed is undefil'd and chaste pronounc't,

Present, or past, as Saints and Patriarchs us'd. (IV.758-62)

Milton here uses the virginal terms of undefiled and chaste to describe this sexuality, inverting their usual association with the virginity that is lost with the advent of sexual experience. In doing so he redefines the "holiest place" (IV.759) of human sexuality not as asexual and virginal celibacy but rather active married sexual relations. 
He then invokes the metaphor of Cupid, "Here Love his golden shafts imploies, here lights / His constant Lamp, and waves his purple wings, / Reigns here and revels" (IV.763-65), to show that it is here in this "pure" wedded intimacy that love is real, and not in such things as the "bought smile" of prostitutes (765-67) - the bought actualisation of base sexual desire; courtly dances, masques or balls (767-68) - scenes of casual erotic desire; or the "starved lover" serenading his "proud" love (769-70) - an idealised love that is not real. The first and last examples show unreciprocated desire which is contrasted with the mutual enjoyment shared by Adam and Eve. What is wrong with the "Court Amours / Mixt Dance, or wanton Mask, or Midnight Bal" (76768 ) is less clear, but "wanton" is also used in the context of Adam and Eve's sexual experience immediately after the fall: "Carnal desire enflaming, hee on Eve / Began to cast lascivious Eyes, she him / As wantonly repaid; in Lust they burne" (IX.1013-15). From this comparison we can see that what Milton is criticising in the former passage is the lustful desire that occurs outside the 'rational' relationship of marriage. But Adam and Eve are already married, and they both engage in the sexual act willingly, so how can this be a problem? The answer must lie in the circumstances surrounding each of these acts. The first occurs at night, after the two humans have paid homage to God (IV.721-35), and within the privacy of their "inmost" (IV.738) "blissful Bower" (IV.690) that was specifically "Chos'n by the sovran Planter, when he fram'd / All things to mans delightful use" (IV.691-92):

other Creature here

Beast, Bird, Insect, or Worm durst enter none;

Such was thir awe of Man. In shadie Bower

More sacred and sequesterd, though but feignd,

Pan or Silvanus never slept, nor Nymph,

Nor Faunus haunted. (IV.705-8)

This natural bedchamber had been ritualistically prepared for the event by Eve, to the accompaniment of heavenly singers:

Here in close recess

With Flowers, Garlands, and sweet-smelling Herbs

Espoused Eve deckt first her nuptial Bed, And heav'nly Quires the Hymenaean sung, What day the genial Angel to our Sire Brought her in naked beauty more adorn'd, More lovely then Pandora, whom the Gods Endowd with all thir gifts, and $\mathrm{O}$ too like In sad event, when to the unwiser Son Of Japhet brought by Hermes, she ensnar'd Mankind with her faire looks, to be avenged

On him who had stole Joves authentic fire. (IV.708-19) 
In contrast, the second act occurs spontaneously in broad daylight, shortly after midday, on a nearby "shadie bank" (IX.1037). We can see therefore that the latter lacks the sacred mystery that elevates the "the Rites / Mysterious of connubial Love" (IV.742-43) from the mating of the other animals. Thus the "pure" physicality of the angels' sexuality must likewise be a "Perpetual Fountain of Domestic sweets", motivated by desires that are "Founded in Reason, Loyal, Just, and Pure" (IV.755) rather than merely physical.

The sexual intimacy of Satan and Sin bears a strong parallel to that of the lapsarian Adam and Eve. For like Adam (IX.1029-33), Satan is overcome with a base desire for physical beauty though in this case it is his own "perfect image" that he sees reflected in Sin (II.764-65); in both cases their moral fall is reflected in the shallowness of their following sexual activity. 


\section{CONCLUSION}

The eroticism embodied in quasi-sexual intimacy of the angels represents for Milton the ultimate evolution of love: a complete union involving both body and soul. The idea that the purpose of the human race to be born from Adam and Eve was to replace those spirits that fell from heaven implies that humankind was ultimately intended to ascend to spiritual form. There is inevitably, in other words, common ground between the human and the angelic. We may therefore understand angelic relationships in human terms. The love between angels embodies the ultimate end of the desire for union that we as human beings feel for one another. We are, however, thwarted from achieving this in its entirety due to our physically and mentally restricted state. This limited capacity is shown by the contrast between Adam's account of his "Union of Mind" intimacy with Eve and Raphael's description of the complete integration of the angels: "Easier then Air with Air, if Spirits embrace, / Total they mix" (VIII.626-27). Our sense of this is only strengthened by our foreknowledge of Eve's impending disobedience.

Milton's revelation of the nature of the angelic spirit gradually unfolding throughout the poem yields this climactic concept of love. Thus the angelic union is the goal to which heterosexual desires as exhibited between Adam and Eve aspire. But also, I argue, it represents - even more closely - the oneness of mind towards which Renaissance male friendships (free of the bounds of earthly sexuality and thus the dangers of sodomy) aspire. While not overt, this tendency displayed by the exclusively male homosociality of the angels in Heaven is implied by their pastoral portrayal. This is thematically congruent with the homosocial and spiritual intimacies portrayed within a similar pastoral setting in both "Damon's Epitaph" and "Lycidas". The ascension to heaven of both Damon and Lycidas offers a pattern for Adam and Eve (and their descendants) as portrayed in Paradise Lost. 
Whether this justification of male homosocial desire by association with angelic union is reflective of Milton's own orientation or experiences is impossible to determine, due to the social and cultural conventions discussed in Chapter Three. It seems likely, however, on the grounds of the repeated joint male-female eroticism within his texts that Milton was on some level bisexual at least in terms of attraction. But even if we reject the likelihood of Milton possessing a same-sex attraction (in addition to opposite-sex), nevertheless the multi-dimensional presence of both these elements strengthens the idea that Milton intended the divine union of the angels to represent both the ultimate destination of heterosexual, homosocial, and even homosexual or bisexual desire. 


\section{WORKS CITED}

Bloom, Harold. How to Read and Why. New York: Scribner, 2000.

Boehrer, Bruce. “'Lycidas': The Pastoral Elegy as Same-Sex Epithalamium.” PMLA 117.2 (2002): 222-236.

—. "Animal Love in Milton: The Case of the 'Ephitaphium Damonis'.” ELH 70.3 (2003): 787 811.

Bray, Alan. "Homosexuality and the Signs of Male Friendship in Elizabethan England." History Workshop 29 (1990): 1-19.

—. Homosexuality in Renaissance England. London: Gay Men's Press, 1982.

—. The Friend. Chicago: University of Chicago Press, 2003.

Bredbeck, Gregory W. "Milton's Ganymede: Negotiations of Homoerotic Tradition in Paradise Regained." PMLA 106.2 (1991): 262-276.

Carver, P. L. "The Angels in Paradise Lost." The Review of English Studies 16.64 (1940): 415-431.

Cerny, Jerome A. and Erik Janssen. "Patterns of Sexual Arousal in Homosexual, Bisexual, and Hetrosexual Men. " Arch Sex Behav 40 (2011): 687-697.

Chaplin, Gregory. “'One Flesh, One Heart, One Soul': Renaissance Friendship and Miltonic Marriage." Modern Philology 99.2 (2001): 266-92.

Cicero. Laelius, on Friendship (Laelius de Amicitia) \& the Dream of Scipio (Somnium Scipionis). Trans. J.G.F. Powell. Warminster: Aris \& Phillips, c1990.

deGruy, Karma. "Desiring Angels: the Angelic Body in Paradise Lost." Criticism 54.1 (2012): 11749.

De Montaigne, Michel. “Of Friendship.” The Complete Works of Montaigne: Essays, Travel Jorunal, Letters. Trans. Donald M. Frame. London: Hamish Hamilton, 1958: 135-144.

Empson, William. Milton's God. Cambridge: Cambridge University Press, 1981.

Escobedo, Andrew. “Allegorical Agency and the Sins of Angels.” ELH 75.4 (2008): 787-818.

Fallon, Stephen M. Milton among the Philosophers: Poetry and Materialism in Seventeenth-Century England. Ithaca: Cornell UP, 1991.

Goldberg, Jonathan. Sodometries: Renaissance Texts, Modern Sexualities. Stanford: Stanford University Press, 1992.

Graham, Elspeth. “'Vain Desire', 'Peverseness' and 'Love's Proper Hue': Gender, Sexuality and Feminist Interest in Paradise Lost." Critical Survey 4.2 (1992): 133-39.

Gross, Barry Edward. "Free Love and Free Will in Paradise Lost." Studies in English Literature, 15001900 (1967): 95-106. 
Guy-Bray, Stephen. Homoerotic Space: The Poetics of Loss in Renaissance Literature. Toronto: University of Toronto Press, 2002.

Holstun, James. “'Will you Rent our Ancient Love Asunder?': Lesbian Elegy in Donne, Marvell, and Milton.” ELH 54.4 (1987): 835-867.

Knott, John R., Jr. “Milton's Heaven.” PMLA 85.3 (1970): 487-95.

Lehnhof, Kent R. “'Nor turnd I weene': Paradise Lost and Pre-Lapsarian Sexuality.” Milton Quarterly 34.3 (2000): 67-83.

Lewalski, Barbara K. "Poetic Tradition, Pastoral." Milton in Context. Ed. Stephen B. Dobranski. Cambridge: Cambridge University Press, 2010. 78-93.

Lewis, C. S. "Preface.” Milton, John. Paradise Lost. New York, NY: Oxford University Press, 1941.

Marilla, E. L. "Milton on Conjugal Love among the Heavenly Angels." Modern Language Notes (1953): 485-486.

Milton, John. “Lycidas.” Justa Edouardo King Naufrago, ab Amicis Moerentibus, Amoris \& Mneias Charin (Obsequies to the Memorie of Mr Edward King). Cantabrigiae: Apud Thomam Buck, \& Rogerum Daniel, Celeberrimae Academiae Typographos, 1638.

Milton, John. Paradise Lost: A Poem in Twelve Books. London: S. Simmons, 1674.

Moshenska, Joe. “'Transported Touch': The Sense of Feeling in Milton's Eden.” ELH 79.1 (2012): 1-31.

Raymond, Joad. Milton's Angels: The Early-Modern Imagination. New York: Oxford University Press, 2010.

Rousseay, George. "Homoplatonic, Homodepressed, Homomorbid." Love, Sex, Intimacy and Friendship Between Men, 1550-1880. Eds. Katherine O'Donnell and Michael O'Rourke. Basingstoke: Palgrave Macmillan, 2003. 12-52.

Sedgwick, Eve Kosofsky. Between Men: English Literature and Male Homosocial Desire. New York: Columbia University Press, 1985.

Shawcross, John T. "Milton and Diodati: An Essay in Psychodynamic Meaning." Milton Studies VII (1975): 127-163.

Smith, Bruce R. Homosexual Desire in Shakespeare's England. Chicago: The University of Chicago Press, 1994.

Stapleton, M. L. “'Thou Art Exact of Taste': The Ars Amatoria as Intertext in Paradise Lost." Comparative Literature Studies 36.2 (1999): 83-109. Web . 25 March 2013.

$<$ http://www.jstor.org/stable/40247204>. 
Stewart, Alan. Close Readers: Humanism and Sodomy in Early Modern England. Princeton: Princeton University Press, 1997.

Sugimura N. K. "'Matter of Glorious Trial': Spiritual and Material Substance in Paradise Lost." New Haven: Yale UP, 2009.

Summers, Joseph H. “The Two Great Sexes in Paradise Lost." Studies in English Literature, 150019002.1 (1962): 1-26. 


\section{WORKS CONSULTED}

Belsey, Catherine. John Milton: Language, Gender, Power. Oxford: Basil Blackwell Ltd, 1988.

Brown, Cedric C. "Letters, Verse Letters, and Gift Texts." Milton in Context. Ed. Stephen B. Dobranski. Cambridge: Cambridge UP, 2010. 35-45.

Chaplin, Gregory. "Education.” Milton in Context. Ed. Stephen B. Dobranski. Cambridge: Cambridge UP, 2010. 281-291.

Dzelzainis, Martin. "Ideas in Conflict: Poltical and Religious Thought During the English Revolution." The Cambridge Companion to Writing of the English Revolution. Ed. N.H Keeble, Cambridge: Cambridge UP, 2001. 32-49.

Evans, J. Martin. “Critical Responses, Recent.” Milton in Context. Ed. Stephen B. Dobranski. Cambridge: Cambridge UP, 2010. 143-154.

Harding, Pitt. "Philosophy." Milton in Context. Ed. Stephen B. Dobranski. Cambridge: Cambridge UP, 2010. 439-448.

Kendrick, Christopher. “Anachronism in 'Lycidas'.” ELH 64.1 (1997):1-40.

Kerrigan, William. The Sacred Complex: On the Psychogenesis of Paradise Lost. Cambridge: Harvard UP, 1983.

Martin, Catherine Gimelli. "Italy.” Milton in Context. Ed. Stephen B. Dobranski. Cambridge: Cambridge UP, 2010. 318-327.

Milton, John. The Major Works, Including Paradise Lost. Oxford: Oxford World's Classics, 2009.

Milton, John. Paradise Lost. Ed. Christopher Ricks. Harmondsworth: Penguin, 1969.

Manlove, Colin. Christian Fantasy: From 1200 to the Present. Indiana: University of Notre Dame Press, 1992.

Labriola, Albert C. "Literary Contemporaries.” Milton in Context. Ed. Stephen B. Dobranski. Cambridge: Cambridge UP, 2010. 338-348.

Le Comte, Edward. “The Perfect Marriage.” Milton and Sex. London: Macmillan, 1978. 85-100.

Patterson, Annabel M. John Milton. London: Routledge, 2014.

Poole, William. "Theology." Milton in Context. Ed. Stephen B. Dobranski. Cambridge: Cambridge UP, 2010. 475-486.

Revard, Stella P. “Classical Literature and Learning." Milton in Context. Ed. Stephen B. Dobranski. Cambridge: Cambridge UP, 2010. 270-280.

Roswenthal, A. M., David Sylva, Adam Safron and J. Michael Bailey. "The Male Bisexuality Debate Revisited: Some Bisexual Men Have Bisexual Arousal Patterns." Arch Sex Behav 41 (2012): 135-147. 
Rousseay, George. "Homoplatonic, Homodepressed, Homomorbid.” Love, Sex, Intimacy and Friendship Between Men, 1550-1880. Eds. Katherine O'Donnell and Michael O'Rourke. Basingstoke: Palgrave Macmillan, 2003. 12-52.

Stretter, Robert. "Cicero on Stage: Damon and Pithias and the Fate of Classical Friendship in English Renaissance Drama." Texas Studies in Literature and Language, 47.4 (2005): 345-365. Summers, Claude J. "Homosexuality and Renaissance Literature, or the Anxieties of Anachronism." South Central Review 9.1 (1992): 2-23.

Suzuki, Shigeo. "Marriage and Divorce.” Milton in Context. Ed. Stephen B. Dobranski. Cambridge: Cambridge UP, 2010. 382-393.

Turner, James Grantham. One Flesh: Paradisal Marriage and Sexual Relations in the Age of Milton. Oxford: Clarendon, 1987.

Wagenknecht, Edward. "Milton in 'Lycidas."” College English 7.7 (Apr 1946): 393-397.

Wittreich, Joseph Anthony, Jr. “Milton’s 'Destin'd Urn': The Art of Lycidas.” PMLA 84.1 (1969): 60-70. 